\title{
Extreme events in the La Plata basin: a retrospective analysis of what we have learned during CLARIS-LPB project
}

\author{
Andrea F. Carril ${ }^{1,2, *}$, Iracema F. A. Cavalcanti ${ }^{3}$, C. G. Menéndez ${ }^{1,2,4}$, A. Sörensson ${ }^{1,2}$, \\ N. López-Franca ${ }^{1,2}$, J. A. Rivera' ${ }^{2,9}$, F. Robledo ${ }^{1,2}$, P. G. Zaninelli ${ }^{1,2}$, T. Ambrizzii ${ }^{5}$, \\ O. C. Penalba ${ }^{2,4}$, R. P. da Rocha ${ }^{5}$, E. Sánchez ${ }^{6}$, M. L. Bettolli ${ }^{2,4}$, N. Pessacg ${ }^{7}$, M. Renom ${ }^{8}$, \\ R. Ruscica ${ }^{1,2}$, S. Solman ${ }^{1,2,4}$, B. Tencer ${ }^{10}$, A. M. Grimm ${ }^{11}$, M. Rusticucci ${ }^{2,4}$, A. Cherchi ${ }^{12}$, \\ R. Tedeschi ${ }^{3}$, L. Zamboni ${ }^{13}$
}

\footnotetext{
${ }^{1}$ Centro de Investigaciones del Mar y la Atmósfera (CIMA/CONICET-UBA), C1428EGA Buenos Aires, Argentina ${ }^{2}$ Instituto Franco-Argentino para el Estudio del Clima y sus Impactos (UMI IFAECI/CNRS), C1428EGA Buenos Aires, Argentina ${ }^{3}$ Center for Weather Forecast and Climate Studies/National Institute of Space Research (CPTEC/INPE), Cachoeira Paulista, 12600-000 São Paulo, Brazil

${ }^{4}$ Departamento de Ciencias de la Atmósfera y los Océanos (DCAO/FCEN), Universidad de Buenos Aires, C1428EGA Buenos Aires, Argentina

${ }^{5}$ Instituto de Astronomia, Geofísica e Ciências Atmosféricas, Departamento de Ciências Atmosféricas, Universidade de São Paulo, 05508-090 Brazil

${ }^{6}$ Facultad Ciencias Ambientales y Bioquímica, Universidad de Castilla-La Mancha, 45071 Toledo, Spain

${ }^{7}$ Centro Nacional Patagónico (CENPAT/CONICET), Puerto Madryn, U9120ACF Chubut, Argentina

${ }^{8}$ Unidad de Ciencias de la Atmósfera, Instituto de Física, Facultad de Ciencias, Universidad de la República, 11400 Montevideo, Uruguay

${ }^{9}$ Instituto Argentino de Nivología, Glaciología y Ciencias Ambientales (IANIGLA/CONICET), 5500 Mendoza, Argentina

${ }^{10}$ School of Earth and Ocean Sciences, University of Victoria, Victoria, V8P 5C2 British Columbia, Canada

${ }^{11}$ Department of Physics, Federal University of Paraná, 81531-980 Curitiba, Brazil

${ }^{12}$ Fondazione Centro Euro-Mediterraneo sui Cambiamenti Climatici, and Istituto Nazionale di Geofìsica e Vulcanologìa, 40127 Bologna, Italy

${ }^{13}$ Mathematics and Computer Science Division, Argonne National Laboratory, Argonne, Illinois 60439, USA
}

ABSTRACT: Extreme climate events over the La Plata basin (LPB) can produce significant impacts due to the importance of the regional agriculture and hydroelectric power production for the local economy. Progress on describing, projecting and understanding extremes in LPB, in the framework of the CLARIS-LPB Europe-South America Network for Climate Change Assessment and Impact Studies in La Plata Basin Project, are reviewed. The paper is based on recent studies and publications, as well as some new diagnostics as indicators of works in progress, and can be considered as an update for the LPB region of previous reviews by Cavalcanti et al. (2015; J Hydrol 523:211-230) and Rusticucci (2012; Atmos Res 106:1-17). Despite the significant advances on regional extremes, some gaps have been identified, and many challenges remain. Much of the recent progress considers temperature and precipitation extremes on timescales varying from synoptic to long-term variability and climate change, essential for impact and vulnerability assessments. Research lines on extremes requiring further efforts include the relative roles of local versus remote forcings, the impact of land use and land management changes, the specific role of soil moisture and land-atmosphere feedbacks as catalysts for heat waves, the impact of the local inhomogeneities in soil moisture, feedback and uncertainties in projections of extremes, as well as seasonal forecast and climate change attribution studies. We suggest combining intensive monitoring and modelling to address these issues.

KEY WORDS: Temperature extremes · Precipitation extremes · La Plata Basin · Climate models · Regional climate change 


\section{INTRODUCTION}

The La Plata Basin (LPB) is a region in southeastern South America (SESA) of $\sim 4144000 \mathrm{~km}^{2}$ that covers parts of Argentina, Brazil, Bolivia, Paraguay and Uruguay. The basin, which is one of the largest on earth, is the most populated region of South America (SA), and relies economically on agriculture and hydroelectric power. Extreme events occurring in the LPB can greatly affect the natural systems of the basin as well as the social and economic sectors.

The region is vulnerable to several types of precipitation extremes, spanning a wide range of scales. On hourly to daily time scales, flash flooding due to intense precipitation events associated with deep convective cells (e.g. Cavalcanti 2012, Cavalcanti et al. 2013, Fernández-Long et al. 2013, Boers et al. 2014a) can destroy buildings and threaten lives. On monthly to seasonal time scales, deficit or surplus precipitation, usually influenced by El Niño-southern oscillation (ENSO) episodes (e.g. Grimm et al. 2000, Berbery \& Barros 2002, Camilloni \& Barros 2003, Carvalho et al. 2004, Cavalcanti 2012, Müller \& Berri 2012, Tedeschi et al. 2014), affect the agriculture, water resources, fluvial transportation, energy supply and the population living in the affected areas. Lastly, drought-like conditions accompanied by warm spells (mostly occurring during the summertime in the LPB; Barrucand et al. 2014) cause unfavorable effects on vegetation and crops and eventually lead to wildfires. Cold and heat outbreaks have a huge impact on agriculture, human health and energy demand. Wintertime cold air outbreaks (e.g. Garreaud 1999, 2000, Vera \& Vigliarolo 2000, Müller \& Ambrizzi 2007, Müller \& Berri 2012) sometimes produce frosts, causing serious damage to crops and fruits. Summertime cold air incursions result in less dramatic variations of temperature, but produce deep convection close to the connection between the northwestern Argentinean Low and the trough to the south of it, forming a low pressure tongue around the saddle point (e.g. Arraut \& Barbosa 2009, Boers et al. $2014 a, 2015)$. The intrusions of tropical air into higher latitudes have been studied in less detail (e.g. Rusticucci \& Vargas 1995b, Rusticucci et al. 2003, Cerne et al. 2007). These intrusions occur close to the Andes between $20^{\circ} \mathrm{S}$ and $30^{\circ} \mathrm{S}$. This region is connected to the climatological position of the South Atlantic Convergence Zone (SACZ) (Seluchi \& Marengo 2000), and SACZ activity on intraseasonal scales plays an important role in the development of the most persistent heat waves (Cerne \& Vera 2011) and extreme rainfall events (Carvalho et al. 2004).
A changing climate leads to changes in the frequency, intensity, duration, timing and spatial extent of extremes, which could result in unprecedented extremes (e.g. Marengo et al. 2009, Seneviratne et al. 2012). In this context, the impacts of climate change on a community or region depend on the severity of the extreme events as well as on the vulnerability of this community or region. Christensen et al. (2007) noted the lack of regional studies related to extreme events and their projections over SA. With this in mind, and under the premise that coordinated efforts are likely to reap greater rewards than individual actions, one of the CLARIS-LPB goals was to advance the understanding of the key processes associated with the occurrence of extremes. Particular attention was paid to the study of trends and projections, as well as to the understanding of the role of the largescale forcing versus the local feedbacks that may lead to the occurrence of extremes. As discussed by Rusticucci (2012), a high spatial and temporal resolution database is a necessary input to the analysis of extreme events. CLARIS-LPB has played an important role in the creation of databases, and the working group on extremes has benefitted from that. Some activities have used the quality controlled daily station data collected by the database working group (Penalba et al. 2014) and the gridded datasets delivered by the project (Tencer et al. 2011, Jones et al. 2013). In other cases, different sets of reanalysis as well as model integrations from international programs (e.g. CMIP3 and CMIP5), from ad hoc experiments (e.g. see Cavalcanti et al. 2015 and references therein) and from the CLARIS (Menéndez et al. 2010b) and CLARIS-LPB regional climate models (RCMs) coordinated experiments (Solman et al. 2013, Sánchez et al. 2015) have been used. At this point, it is worth noting that although regional climate modeling has undergone continuous development during the last decades, in the IPCC AR4, all the regionalscale information for South America was taken from general circulation models (GCMs). Following Roads et al. (2003) and Marengo et al. (2010a), a new set of coordinated RCMs over South America was available (e.g. Menéndez et al. 2010a,b) in the framework of CLARIS (Boulanger et al. 2010). Nevertheless, most of the information related to extreme events was derived from the CMIP3 global models (e.g. Menéndez \& Carril 2010). During the CLARIS-LPB project, some studies on extremes were carried out by analyzing simulations of RCMs integrated in the framework of both the CLARIS (e.g. Carril et al. 2012) and CLARIS-LPB (e.g. Cavalcanti et al. 2015, LopezFranca et al. 2015) projects. Moreover, because the 
RCMs used to simulate South American climate in the framework of both CLARIS and CLARIS-LPB projects were originally developed for Europe and North America, the RCMs were evaluated over South America (e.g. Carril et al. 2012, Solman et al. 2013), and sensitivity experiments were carried out to attain an optimal model setup for optimum performance (Solman \& Pessacg 2012).

This paper focuses on what we have learned during the CLARIS-LPB EU FP7 project regarding the occurrence of extremes over LPB (without excluding the works performed outside the project).

\section{TEMPERATURE EXTREMES}

In a previous review paper about the extremes in temperature, Rusticucci (2012) highlighted the geographical imbalance with respect to the number of published studies on temperature extremes in South America, limiting our understanding of this over the continent, mainly due to the lack of data. In this section, we highlight the advances on temperature-related extremes reached in the last years, during the CLARIS-LPB project. Definitions of indices cited in the paper are summarized in Table 1. Most of these indices were defined by the Expert Team on Climate Change Detection and Indices (ETCCDI; Zhang et al. 2011).

\subsection{Variability and trends in temperature extremes}

When the project began, we knew that the strongest changes in daily maximum (TX) and minimum temperature (TN) values in a vast region of LPB had been registered in summer: TN was increasing (but its interdiurnal standard deviation was decreasing), and TX was mostly decreasing (e.g. Sansigolo \& Kayano 2010). Overall, negative trends had been documented for the number of cold nights and warm days per summer, while the number of warm nights and cold days had increased at certain locations. A positive trend in the summertime mean temperature in central-northern Argentina had been mostly explained by the increasing frequency of warm events (see e.g. Barrucand \& Rusticucci 2001, Rusticucci \& Barrucand 2004, Vincent et al. 2005). Focusing on long-term variabilities, Vargas \& Naumann (2008) showed that the occurrence of wet days is one of the main factors driving secular variations of TN and TX and variations in precipitation.
CALRIS and CLARIS-LPB allowed us to advance knowledge about temperature extremes over the Argentinean sector of LPB, and to start analyzing series of temperature extremes over Uruguay for which there was no previous literature on the subject.

Over the Argentinean sector of the LPB, it was found that return values of the highest (lowest) maximum (minimum) temperature of the year denote changes in the return values related to decadal variability (Rusticucci \& Tencer 2008, Tencer \& Rusticucci 2012). In particular, over Buenos Aires Central Observatory after 1977, the frequency of occurrence of high values of TN (TX) has been greater (lower) than before 1977, leading to a decrease in the annual temperature range (Rusticucci \& Tencer 2008). The frequency of occurrence of extremes in the south of the Argentinean LPB has changed throughout the last century, and changes go beyond the climatic jump, or discontinuity, of 1976 (Tencer \& Rusticucci 2012). The intensity of warm extremes in both TX and TN has decreased over the period 1941-2000, while the frequency of occurrence of TX (TN) has decreased (increased) from 1941-1960 to 1961-1980 (1961-1980 to 1981-2000). In contrast, the intensity of cold extremes has mostly decreased. Rusticucci \& Tencer (2008) and Tencer \& Rusticucci (2012) illustrate that changes in the intensity and frequency of occurrence of annual and daily extremes are not always consistent, implying that the behavior of the most extreme value in the year is not always equivalent to the behavior of the upper or lower $10 \%$ tail.

Over Uruguay, Renom (2009) reported on the existence of negative trends in the number of warm (cold) days and cold (cold) nights for summer (winter) and on warming in autumn night temperatures. Trends in temperature indices were not affected by any significant trend in the occurrence of summer heat waves. Moreover, preliminary results by Renom et al. (2014) show a negative trend in the occurrence of frost events during the cold months (May to September), with May being the month with largest decrease in the occurrence of frosts, in agreement with the warming trends in night temperatures in autumn.

\subsection{Remote forcings}

Regional climate is modulated by the interaction of local and remote forcings. Regarding the large-scale patterns that lead to the occurrence of extremes, preproject knowledge related the interannual variability of temperature extremes with the phases of ENSO 
Table 1. A summary of the indices cited throughout the text, for both temperature and precipitation (Pp). The percentiles of reference are calendar day percentiles, centered on a $5 \mathrm{~d}$ window and for the base period 1961 to 1990

\begin{tabular}{|c|c|c|c|c|}
\hline No. & Index & Name & Description & Units \\
\hline 1 & TN10 & Cold nights & Percentage of days when $\mathrm{TN}<10^{\text {th }}$ percentile & $\%$ \\
\hline 2 & TX10 & Cold days & Percentage of days when TX $<10^{\text {th }}$ percentile & $\%$ \\
\hline 3 & TN90 & Warm nights & Percentage of days when $\mathrm{TN}>90^{\text {th }}$ percentile & $\%$ \\
\hline 4 & TX90 & Warm days & Percentage of days when TX $>90^{\text {th }}$ percentile & $\%$ \\
\hline 5 & WSDI & Warm spell duration index & $\begin{array}{l}\text { Annual count of days with } \geq 6 \text { consecutive } \\
\text { days when } T X>90^{\text {th }} \text { percentile }\end{array}$ & $\left(\mathrm{d} \mathrm{yr} \mathrm{r}^{-1}\right)$ \\
\hline 6 & WSDI_NUM & Frequency of warm spells & Annual frequency of WSDI & (events $\left.\mathrm{yr}^{-1}\right)$ \\
\hline 7 & CSDI & Cold spell duration index & $\begin{array}{l}\text { Annual count of days with } \geq 6 \text { consecutive } \\
\text { days when } \mathrm{TN}<10^{\text {th }} \text { percentile }\end{array}$ & $\left(\mathrm{d} \mathrm{yr}^{-1}\right)$ \\
\hline 8 & $\mathrm{CDD}$ & Consecutive dry days & $\begin{array}{l}\text { Maximum number of consecutive days with } \\
\mathrm{Pp}<1 \mathrm{~mm} \mathrm{~d}^{-1}\end{array}$ & (no. d) \\
\hline 9 & DIER75 & $\begin{array}{l}\text { Intensity of daily extreme } \\
\text { precipitation }\end{array}$ & $\begin{array}{l}\text { The ratio between the monthly-accumulated } \\
\text { extreme precipitation and the number of days } \\
\text { with extreme precipitation, where extreme } \\
\text { precipitation is when } \mathrm{Pp}>75^{\text {th }} \text { percentile }\end{array}$ & $\left(\mathrm{mm} \mathrm{d}^{-1}\right)$ \\
\hline 10 & Rx5day & $5 \mathrm{~d}$ precipitation & $\begin{array}{l}\text { Amount of monthly maximum of consecutive } \\
5 \mathrm{~d} \text { precipitation }\end{array}$ & $(\mathrm{mm})$ \\
\hline 11 & SPI & $\begin{array}{l}\text { Standardized precipitation } \\
\text { index }\end{array}$ & $\begin{array}{l}\text { The number of standard deviations that the } \\
\text { observed value would deviate from the long- } \\
\text { term mean for a normally distributed random } \\
\text { variable. Because precipitation is not normally } \\
\text { distributed, a transformation is first applied so } \\
\text { that the transformed precipitation values follow } \\
\text { a normal distribution. A separate SPI value is } \\
\text { calculated for a selection of time scales }\end{array}$ & (dimensionless) \\
\hline 12 & DHI & Drought hazard index & $\begin{array}{l}\text { Index based on drought frequencies weighted } \\
\text { by severity, with } 3 \text { categories identified through } \\
\text { the tertiles of its spatial distribution }\end{array}$ & (dimensionless) \\
\hline
\end{tabular}

(e.g. Müller et al. 2000, Rusticucci \& Vargas 2001, Barros et al. 2002), although large inter-monthly variability had been noticed (e.g. Grimm et al. 2000, Rusticucci \& Vargas 2002, Rusticucci et al. 2003). In particular, on the intraseasonal scale, the phases of the Madden-Julian Oscillation (MJO) display a consistent signal with the wintertime temperature variability in the LPB (Naumann \& Vargas 2010). Some other authors have discussed processes associated with cold surges (e.g. Müller 2007, Müller \& Berri 2007, Müller \& Ambrizzi 2010). In particular, the occurrence of wintertime cold outbreaks leading to generalized frosts is usually associated with wave trains propagating inside the subtropical and polar waveguides that merge just before entering the continent, favoring anticyclonic anomalies and intense cold advection (Müller \& Ambrizzi 2007). The mechanisms related to the tropical air intrusions have been less studied. On one hand, the physical processes related to the occurrence of heat waves in central-north Argentina are related to the activity of synoptic-scale waves (Rusticucci \& Vargas 1995a), but on the other hand, the intraseasonal variability has a strong impact on the evolution of the summer- time anomalies (Cerne et al. 2007). A large number of persistent summertime heat waves occur in association with the strengthening of anticyclonic anomalies (embedded in a wave train excited by anomalous convection at the equatorial western and central Pacific) that are in turn associated with the active phase of the SACZ (Cerne \& Vera 2011).

During the project, the large-scale atmospheric anomalies in which temperature extremes are embedded have been further characterized. A principal finding is that the results are non-stationary: the relationships have changed over time (Renom et al. 2011). Before 1976, the interannual variability of the summertime cold nights (TN10; see Table 1) coincided with the negative phase of the southern annular mode (SAM), related to cyclonic anomalies centered off Uruguay and favoring the entrance of cold air from the south. The interannual variability of the wintertime warm nights (TN90; see Table 1) was dominated by ENSO teleconnections, driving anomalous northerly warm winds into Uruguay. After 1976, the summertime cold-nights have been associated with an isolated vortex at upper levels over southeastern South America. Moreover, as ENSO 
teleconnections are weakened, the variability of the wintertime TN90 is dominated by a barotropic pattern of anticyclonic anomalies located in the South Atlantic Ocean and cyclonic anomalies over South America. This configuration also strengthens the northward flow of warm air over Uruguay. Renom et al. (2011) suggest that changes in El Niño evolution after 1976 may have played a role in altering the relationship between occurrence of extreme temperatures in Uruguay and the atmospheric circulation.

\subsection{Projections and uncertainties}

When CLARIS-LPB started, we knew that reanalysis had to be used with caution for studies of the magnitude of day-to-day temperature changes. Rusticucci \& Kousky (2002) had documented that the NCEP reanalysis is able to reproduce the timing of midlatitude extreme events in temperature, but fails to capture the amplitude and frequency of extremes in both subtropical regions and areas of high relief. During the CLARIS-LPB project, Zaninelli et al. (2015a,b) explored the uncertainty of TX and TN from reanalysis in SESA. Three different reanalyses (NCEP/NCAR, Kalnay et al. 1996; ERA40, Uppala et al. 2005; and 20CR/NOAA, Compo et al. 2011) have been compared using a novel daily gridded dataset of minimum and maximum surface temperature (Tencer et al. 2011; hereafter TNCR dataset) and with integrations of 4 regional climate models driven by boundary conditions from ERA40 (details are in Carril et al. 2012). Fig. 1 summarizes how well RCMs (upper panels) and reanalyses (lower panels) capture the geographical patterns of anomalies of the 75th percentile of TX for DJF (warm extremes, left panels) and of the 25th percentile of TN for JJA (cold extremes, right panels) in SESA using Taylor diagrams (Taylor 2001). Those diagrams are a graphical representation of the statistical relationships between 2 random variables: (1) the series of the P75 of TX from TNCR (our reference) and (2) the series of the P75 of TX from other datasets. To estimate the 3 statistics (standard deviation, correlation and centered root mean square difference), input series must have the same dimension. Therefore, in the case of the ensemble, the input series is the mean among the P75 of TX series of every climatology. In addition, all the statistics are calculated after removing the spatial mean value of each dataset. In general, the ensemble mean (either for regional models or reanalyses) has a good performance relative to each individual ensemble members for both variables and both seasons, which corroborates previous outcomes (e.g. Menéndez et al. 2010a). The spread between ensemble members for TX in DJF is larger than for TN in JJA for both regional models and reanalyses. Note that the inter-member spread is similar for the regional models and reanalyses in both seasons, and that errors are similar for both the models ensemble and the reanalyses ensemble. Based on that similarity, Zaninelli et al. (2015a,b) concluded that maximum/ minimum surface temperature from reanalysis cannot be used to validate regional models, highlighting the existing uncertainties for studying extremes in temperature using both state-of-the-art RCMs and gridded databases.

Assuming that TNCR is an appropriate climatology to validate models in the LPB region, the capability of the CLARIS-LPB RCMs to capture the interannual variability of extremes in TX and TN is displayed in Fig. 2. The figure depicts the indices for warm days and cold nights (TX90 and TN10, respectively); (see Table 1), representative of the northern-LPB $\left(15^{\circ}-25^{\circ} \mathrm{S} ; 55^{\circ}-45^{\circ} \mathrm{W}\right)$ and southern-LPB $\left(25^{\circ}-35^{\circ} \mathrm{S}\right.$; $60^{\circ}-50^{\circ} \mathrm{W}$ ) regions (NLPB and SLPB, respectively) for the $11 \mathrm{yr}$ period in which the TNCR climatology and the integrations overlap (the mean spatial structure of the fields can be found in Lopez-Franca et al. 2015). As a first criterion, we consider the ensemble as 'satisfactory' for simulating interannual variability of the index if (1) the observed index correlates well with the ensemble mean index and if (2) its observed annual value is contained within the simulated min-max range of the ensemble mean. In general, this criterion is fulfilled in both regions. Nevertheless, the spread among the members of the ensemble is somewhat large: in many cases, the ensemble uncertainty (i.e. the min-max range) is larger than the interannual variability of the ensemble mean, limiting the assessments of the models. The correlation between the ensemble mean and TNCR is best for the NLPB for both indices. Similarly, the inter-model spread also tends to be lower in the NLPB. This pattern suggests that models have more difficulties simulating the extremes of TX and TN in the SLPB. This result is consistent with the fact that the average temperature bias tends to be higher in the SLPB than in the NLPB (e.g. Fig. S11.25 in Christensen et al. 2007). The reasons behind this pattern are not entirely clear, and are an active research topic. Menéndez et al. (2016, this Special) showed that in the SLPB, the soil influences the variability of temperature through evapotranspiration, while in the NLPB, this process has a relatively minor significance. Larger errors in the SLPB may thus suggest problems simulating local feedbacks between precipitation, soil moisture and temperature in that 

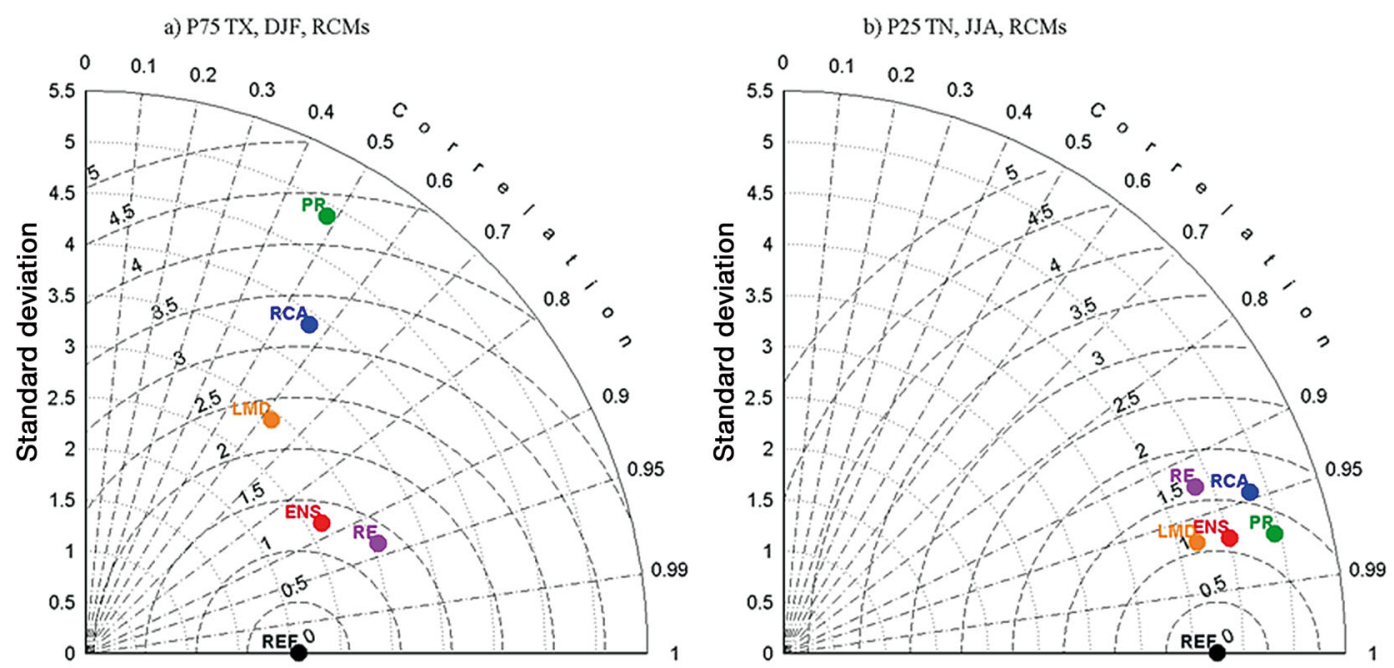

c) P75 TX, DJF, Reanalysis
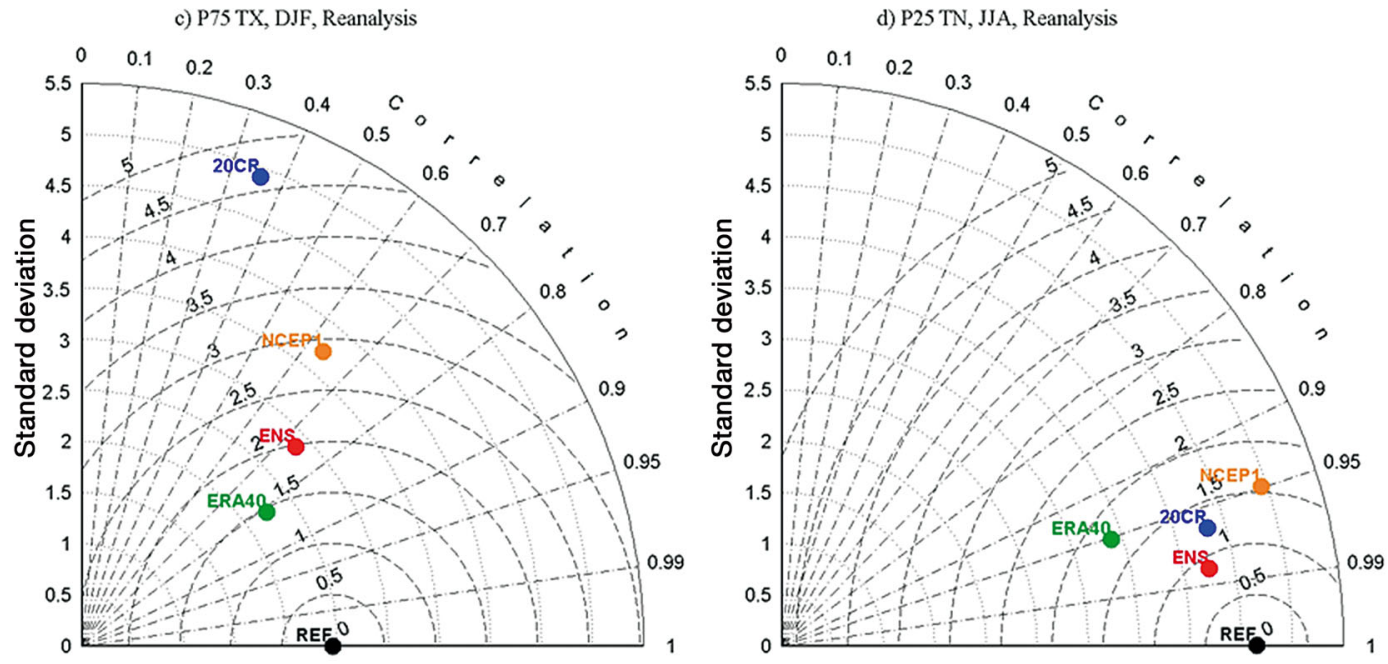

Fig. 1. Taylor diagrams illustrating the agreement or disagreement between the spatial anomalies in temperature from different data sets. The upper panels show regional models (PROMES in green, RCA in blue, LMDZ in orange, REMO in violet and the multi-model ensemble [ENS] in red). The bottom panels show reanalysis (ERA 40 in green, 20CR in blue, NCEP in orange and the multi-reanalysis ensemble [ENS] in red). In all the panels, TNCR is the climatology of reference (REF is the black point), and the domain is SESA. Each panel illustrates 3 statistics: the standard deviation (vertical axis), the correlation coefficient (axial) and the mean root square error (concentric). Left column is for threshold of warm extremes in maximum temperature in DJF, and right column is for cold extremes in minimum temperature in JJA

area. This process is more important in summer, and thus influences TX90. In winter, models typically underestimate rainfall in SLPB (Solman et al. 2013), suggesting that related variables, such as cloud cover or wind, may also be wrong. Lopez-Franca et al. (2015) showed the sensitivity of TN to variations in cloud cover and meridional wind in LPB.

Other CLARIS-LPB participants have explored the ability of the IPCC AR4 global models to simulate mean values, interannual variability and trends of annual indices of extremes based on TN. Results show that in the lowlands of the LPB and for the last decades of the 20th century, the models represent the number of warm nights better than the number of frost days (Rusticucci et al. 2010). The models are also able to capture the positive trend observed in the warm nights during the last decades (Marengo et al. 2010b).

Regarding climate change projections of warm (cold) days (nights) over South America (indices 1 to 4 in Table 1), using a subset of CLARIS-LPB RCMs, Lopez-Franca et al. (2015) found that the areas where the warm nights are projected to increase more than warm days are also those areas where TN is projected to increase more than TX in summer, as is the case for the LPB. The lower increase in warm day than warm night occurrence over the LPB under future conditions could reflect the effects of increases 

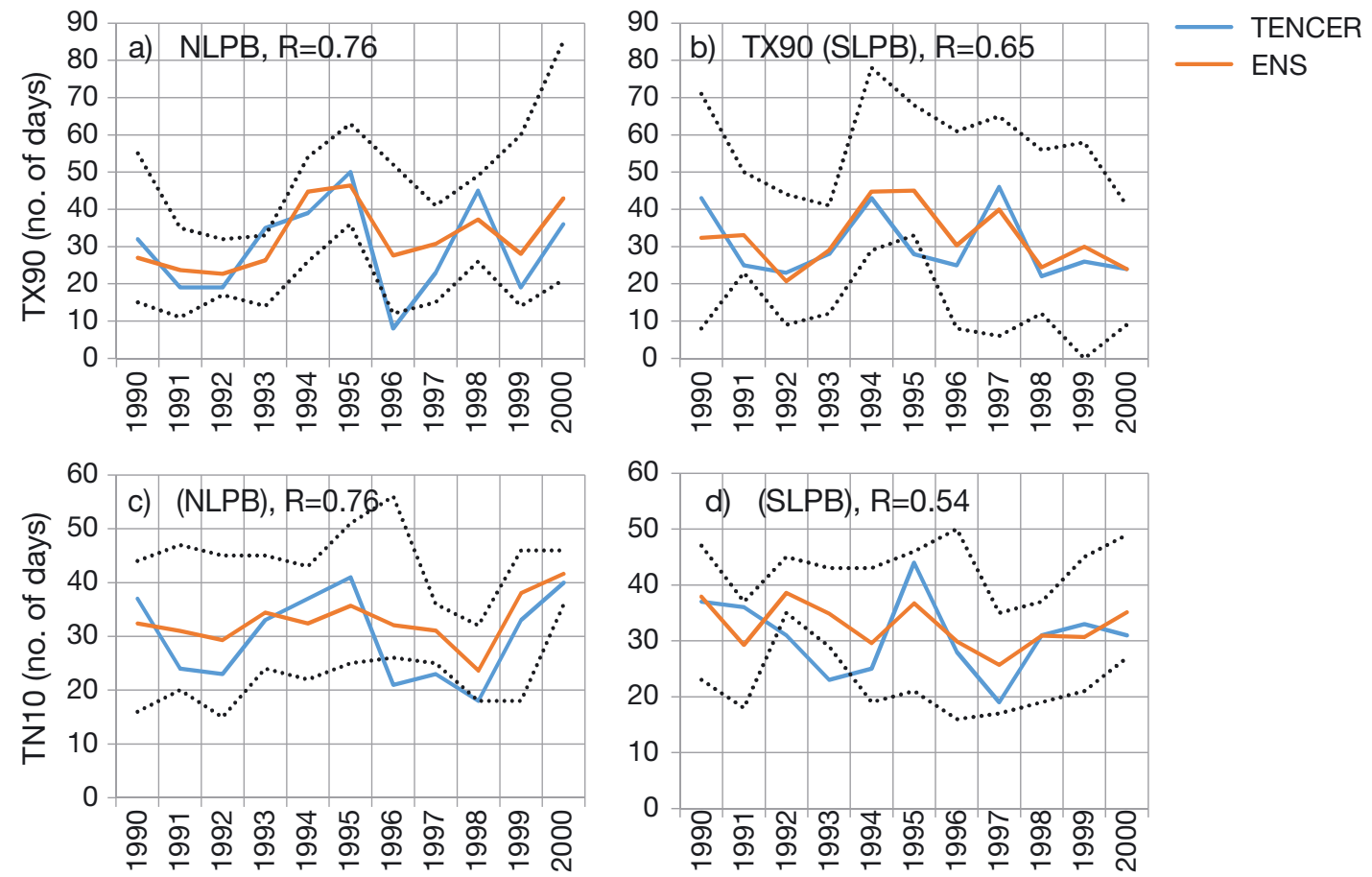

Fig. 2. Interannual variability of extremes in 2 boxes representing the north-LPB region (left column) and south-LPB region (right column). First row is for TX90 (warm day-times) and second row for TN10 (cold nights). Each panel displays time series according to TNCR climatology (blue), the ensemble mean (red), the correlation coefficient between them (R) and a measure of the inter-model spread (max-min range; dotted lines). Models in the ensemble are PROMES, ETA, REGCM3, REMO, LMDZ, MM5 and RCA

in cloudiness over the LPB domain under future conditions (Lopez-Franca et al. 2015). Two main factors are involved related to the cloud effect. First, the cloud effect tends to decrease temperature during the daytime (TX) because clouds reflect the solar radiation. Second, clouds enhance the greenhouse warming during nighttime, increasing TN. Both factors tend to damp the diurnal temperature range. This result is consistent with Zhou et al. (2009), who found that large decreases in diurnal temperature range reflect the effects of increases in cloudiness over the LPB under future conditions (see their Fig. 2). A factor that could contribute to a dampening of the projected increase of TX is the response of summer evapotranspiration in the LPB (Menéndez et al. 2016).

A complementary analysis, using the same subset of CLARIS-LPB RCMs as Lopez-Franca et al. (2015), considers annual warm spell indices (indices 5 and 6 in Table 1) and is displayed in Fig. 3. TheHadEX2 dataset (Donat et al. 2013), available on a $2.5^{\circ} \times$ $3.75^{\circ}$ longitude-latitude grid from the CLIMDEX project (Alexander et al. 2006; www.climdex.org) is used to assess the simulated ETCCDI temperature indices. It is known that the models' surface temperature has a warm bias in the LPB (Sánchez et al. 2015). That bias is probably related to a deficit of precipitation in the LPB (Menéndez et al. 2016). Consecutive extremes in TX (WSDI, see Table 1) also show a warm bias: models overestimate the duration of warm spells by a rate of about 60 to $150 \%$ in LPB. Nevertheless, the geographical structure of the field is well captured (WSDI increases from SW to NE; Fig. 3a,b), and the pattern of mean number of warm spells registered per year (Fig. 3c) is similar to that of WSDI (northern LPB is affected by particularly large and frequent warm spells). Projections to the end of the 21st century (forced by SRES-A1B) indicate that changes in the duration and frequency of warm spells have a similar geographical pattern, with a maximum north of $30^{\circ} \mathrm{S}$ and in coastal regions (Fig. 3d,e). The northern portion of the LPB appears as a particularly vulnerable region to the occurrence of warm spells in the future, with spells up to $600 \%$ larger and $400 \%$ more frequent than in present climate (in the southern portion of the LPB, the rate of change is about $200 \%$ larger and more frequent). This result could be interpreted in the context of previous studies. Results by Junquas et al. (2012) confirm that future summertime rainfall variability in SESA is strongly related to changes in the SACZ dipole pattern, associated with an increase in the frequency of the 
a) OBS

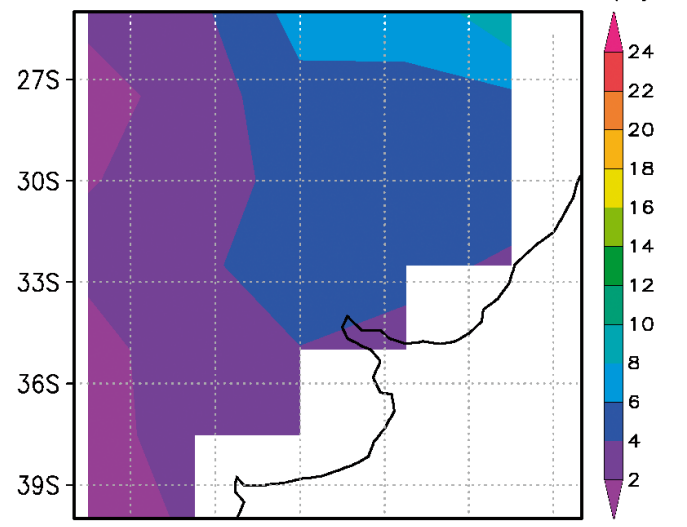

b) Near Present

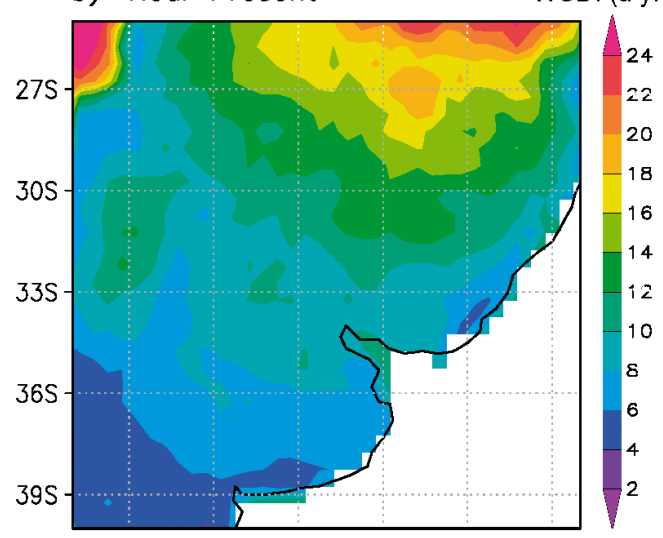

d) Climate Change

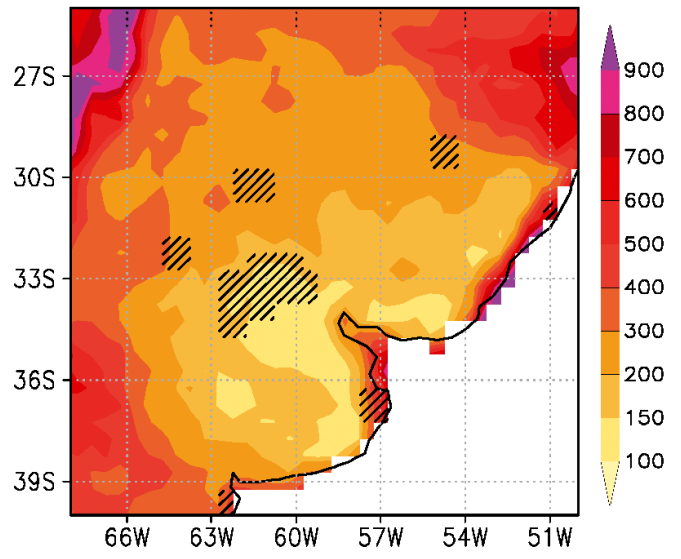

dipole events (i.e. above-normal rainfall in SESA and below-normal rainfall in the SACZ region). This projection could play a role in modulating the increasing trend of heat waves in the southern portion of the LPB; Cerne \& Vera (2011) have shown that $73 \%$ of the heat waves in the southern portion of the LPB are associated with intensified SACZ activity. Regarding cold spells, when calculating the cold spell duration index (CSDI, see Table 1) fields
Fig. 3. (Left column) Warm spell duration index (WSDI). (Right column) Mean number of warm spells per year (WSDI_NUM). First row shows the HadEX2 dataset for present period (1991-2010), second row shows the multi-model ensemble mean (RCM-ENS) for present period, and third row shows the projected climate change (2079-2098, SRESA1B) expressed as percentage differences. Models in the ensemble are PROMES, RCA3, REMO and LMDZ with regional configuration. Robustness of the climate change signal is tested following Kendon et al. (2008). Striped areas indicate zones where the anthropogenic climate change signal is not significant at $95 \%$
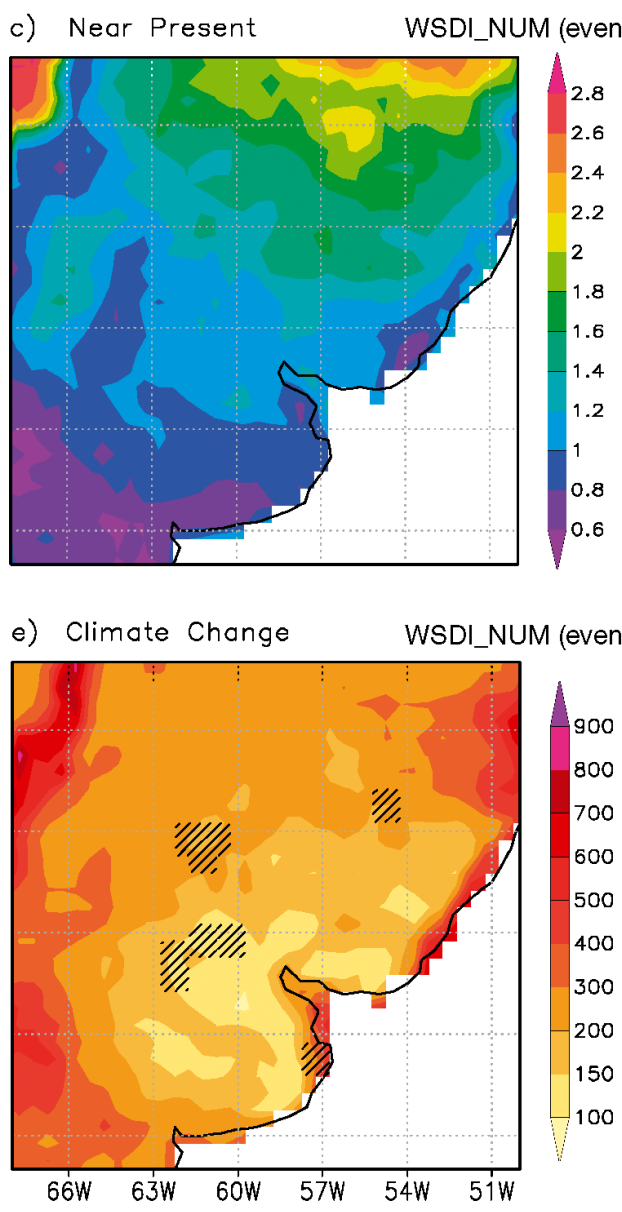

from both HadEX2 and RCMs, the CSDI is almost constant and close to zero in the LPB, suggesting that the commonly accepted definition for CSDI is not appropriate for the LPB region. Previous works on cold spells in Argentina note that using the 25th percentile as the threshold for cold days (instead of the 10th percentile imposed by ETCCDI), the typical duration for summertime (wintertime) cold waves are 4 (6) d (Rusticucci \& Vargas 2001). 


\section{PRECIPITATION EXTREMES}

Here, we highlight the advances during CLARISLPB related to the occurrence and intensity of wet/dry episodes and spells, as well as recent observed trends, projections and uncertainties.

\subsection{Variability and trends in wet and dry extremes}

Research on interannual variability and trends in rainfall extremes has been increasing during recent years. In particular, when CLARIS-LPB started, we knew that (1) the annual cycle of daily events is strongly related to the annual cycle of monthly precipitation (Penalba \& Robledo 2010); (2) trends in extremes in the period 1961-2000 are similar to the trends in the total annual rainfall (Haylock et al. 2006); and (3) trends in frequencies of extreme daily precipitation have been positive in central and eastern Argentina (period 1959-2002, Re et al. 2006) and in the subtropical sector of Brazil (Groisman et al. 2005) since the 1940s.

Outcomes from CLARIS-LPB show that the frequency of monthly wet extremes is greatest in the southern portion of the LPB (Cavalcanti et al. 2015). Moreover, positive trends in the frequency of occurrence of daily extreme precipitation events in the LPB have been observed (period 1961-2000; Penalba \& Robledo 2010). The largest increase occurs in southern Brazil, while negative trends are observed in winter in the southern LPB. The changes in the frequency of daily extremes have had an impact on the annual cycle of rainfall. In particular, Sugahara et al. (2009) documented positive trends in the frequency of days with extreme rainfall in Sao Paulo and showed that the threshold of the 90th percentile has increased by $40 \mathrm{~mm}$ in the period 1933-2005.

Trends in the intensity of daily extreme rainfall are illustrated by changes of the DIER75 index (see Table 1) and displayed in Fig. 4. DIER75 has increased (decreased) over vast areas of the LPB in fall and spring (winter). In summer, changes are spatially less uniform: DIER75 has decreased (increased) over central-east Paraguay, Parana and Mato Grosso (Minas Gerais, Rio Grande do Sul and the western Argentinean sector of the LPB).

From the synoptic climatology perspective, the study of the occurrence of daily rainfall extreme events and the associated circulation could be addressed through either a circulation-to-environment approach (in which the classification of weather patterns into categories is first performed and then related to an extreme event) or an environment-to-circulation approach (in which a particular extreme event determines which days are classified) (Yarnal \& Draves 1993). The literature on South American synoptic climatology has mostly dealt with precipitation extreme events from the latter approach (e.g. Alessandro \& Lichtenstein 1996, Alessandro 1998, Carvalho et al.

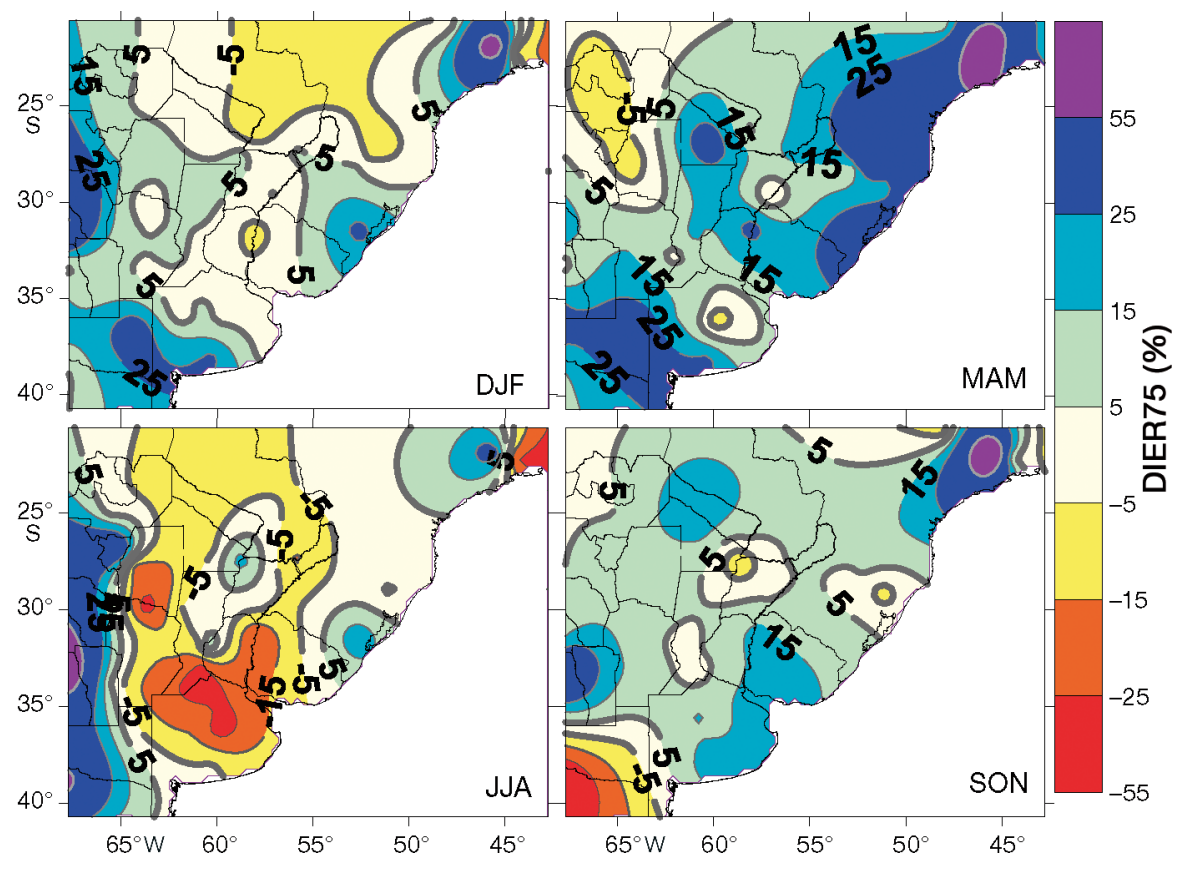

Fig. 4. Observed changes of DIER75 between 1961-1975 and 1980-1996, for the austral summer (DJF), autumn (MAM), winter (JJA) and spring (SON). Seasonal mean values of the percentile $75^{\text {th }}$ are in Fig. 15 in Cavalcanti et al. (2015) 
2002, Labraga et al. 2002, Bischoff \& Vargas 2006, Cavalcanti 2012). The former approach has received less attention (e.g. Chaves \& Cavalcanti 2001, Solman \& Menéndez 2003, Bettolli \& Penalba 2014). During CLARIS-LPB, Penalba \& Bettolli (2011) employed a circulation-to-environment scheme to identify sea level pressure types and to associate these types with precipitation events of the central Pampas region during summer and winter. They studied frequency, distribution, temporal variability and the probability of daily rainfall conditioned to each circulation type. The probability of summer dry days is enhanced by the most persistent circulation type, corresponding to an intensification of the southern Atlantic anticyclone, which diverts perturbations to the south. Heavy rainy days are benefited by the occurrence of a cyclonic anomaly at the center of the continent associated with a cold front passage. Winter dry days are favored by a high-pressure system that extends from the Atlantic Ocean to the center of the continent. Heavy rainy days are benefited by a high-pressure system at the south of the continent, enhancing an anomalous flow from the east-southeast to the central region of Argentina and a corresponding moisture advection at low levels. The authors also assessed the ability of 17 atmospheric global circulation models to simulate the daily rainfall events in the Pampas (characterized by indices defined in terms of counts of days crossing thresholds) and the synoptic structures associated with each group. Most of the models are able to reproduce the observed seasonal differences between the statistics of daily rainfall fairly well. In particular, the relation between circulation patterns and rainfall in winter is better represented than in summer, due to the models' ability (deficiency) to reproduce synoptic scale patterns (small-scale processes) associated with the wintertime (summertime) precipitation (see Table 4 in Bettolli \& Penalba 2014). The projections for the 21st century suggest an increase in the variability of daily rainfall, with a trend of reduction of the summer circulation patterns associated with dry days and an increase of the frequencies of the patterns associated with rainfall over the Pampas region.

Extratropical cyclones are particularly relevant atmospheric systems affecting the weather conditions in the LPB. The western South Atlantic Ocean is a region with a high frequency of these systems (e.g. Sinclair 1994, 1995, 1997, Simmonds \& Keay 2000a,b, Hoskins \& Hodges 2005). During CLARIS-LPB, Pereira (2013) investigated the relationship between cyclogeneses and extreme rainfall over the LPB. Reboita et al. (2010) confirmed the existence of 3 main regions with high frequencies of cyclogenesis over the southwestern South Atlantic Ocean: the south/southeast coasts of Brazil, the Uruguayan and the extreme southern Brazilian coasts (UsB) and the southern coast of Argentina. For UsB, Pereira (2010) showed that cyclones are related to extreme rainfall events over the LPB (Fig. 5). When all cyclones are considered, a large density of event occurs eastward of Uruguay (Fig. 5a), and in the composite of rainfall extremes (85th percentile; Fig. 5b), the most intense values are located over southern Brazil, Uruguay and northeast of Argentina. The spatial pattern of rainfall extremes in Fig. 5b is similar to that found by Arraut \& Barbosa (2009) associated with high frequency of frontogenesis over central-northern Argentina. This similarity occurs because most of the cyclogeneses in UsB are of extratropical type with associated cold and warm fronts. For the initially most intense cyclogeneses, the density is larger over the ocean (Fig. 5c), and the associated composite of rainfall extremes (85th percentile) shows most intense values covering southern Brazil, northeastern Argentina and Uruguay and extending southeastward over the ocean (Fig. 5d). The cyclogeneses density is sensitive to the choice of the initial cyclonic vorticity threshold (Reboita et al. 2010), and furthermore, when intense cyclones occur, the area impacted by extreme rainfall increases. Seasonal analysis of the relationship between the density of the cyclones and extreme precipitation (not shown) indicates that the area affected by extremes is larger during winter and spring than during the rest of the year.

Comparing wet and dry extremes, Cavalcanti et al. (2015) showed that the frequency of observed monthly wet extremes is higher than the frequency of dry extremes in the whole LPB region. Before CLARIS-LPB, the literature about droughts mainly referred to the rainfall conditions over southern South America during La Niña conditions. Dry conditions are related to positive pressure anomalies (Barrucand et al. 2007) and to negative anomalies in the moisture transport both from the Amazonia and from the Atlantic Ocean (Labraga et al. 2002). Although several indices have been used to characterize drought events in the Pampas (e.g. Scian \& Donnari 1997, Minetti et al. 2007, Serio et al. 2010), intercomparison of these studies is not an easy task. During CLARIS-LPB, we used the standardized precipitation index (SPI, McKee et al. 1993; see Table 1), an optimum index for studying droughts in the LPB (Penalba \& Rivera 2015). Results for 1961-2008 indicate that, on average, the LPB is affected by moderate long-term (12 mo) drought conditions (SPI12 
a) Annual density of cyclones

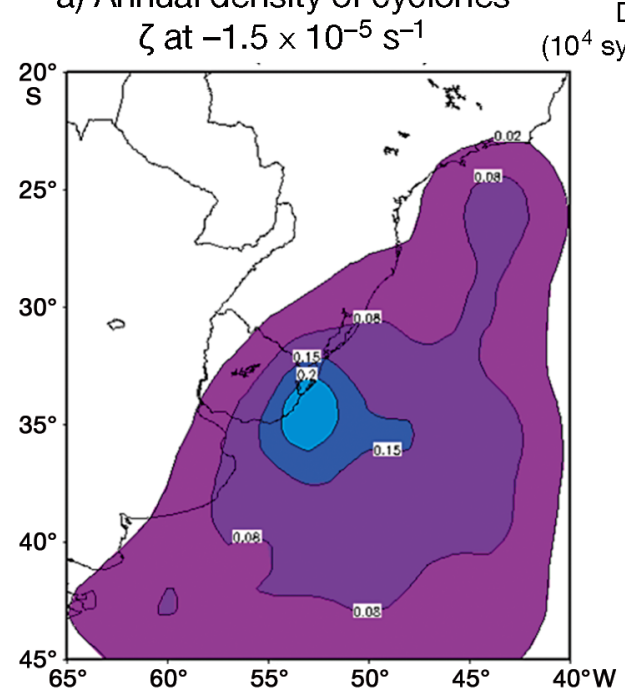

c) Annual density of cyclones

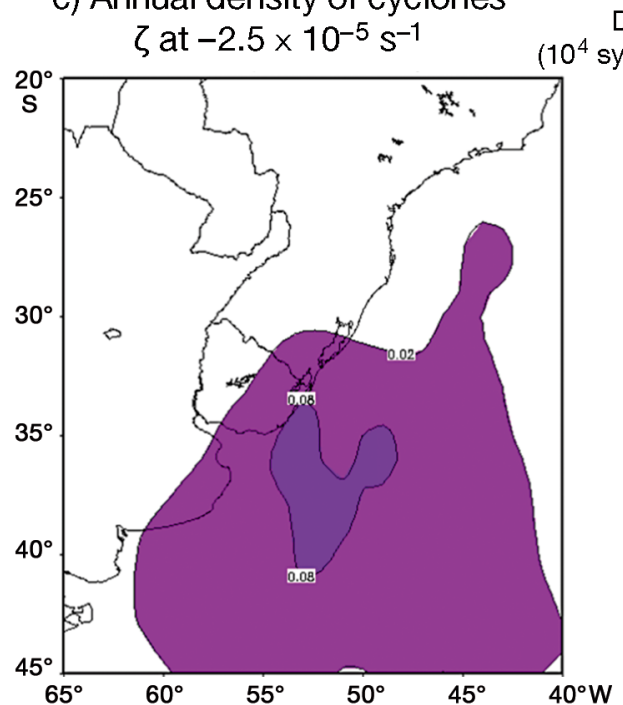

Density tems km-2

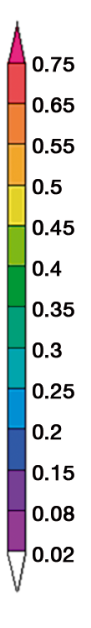

Density

tems km-2 b) Precipitation extremes $\zeta$ at $-1.5 \times 10^{-5} \mathrm{~s}^{-1}$

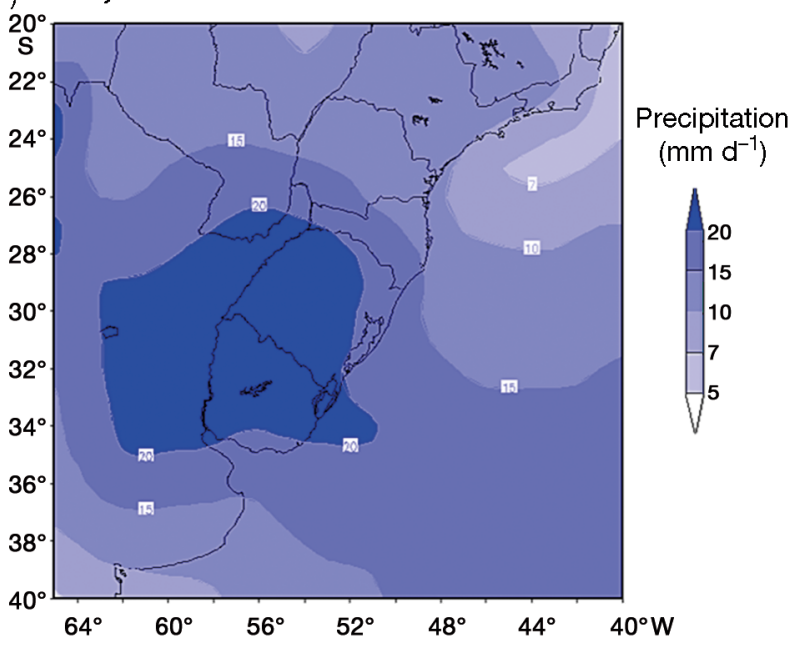

d) Precipitation extremes
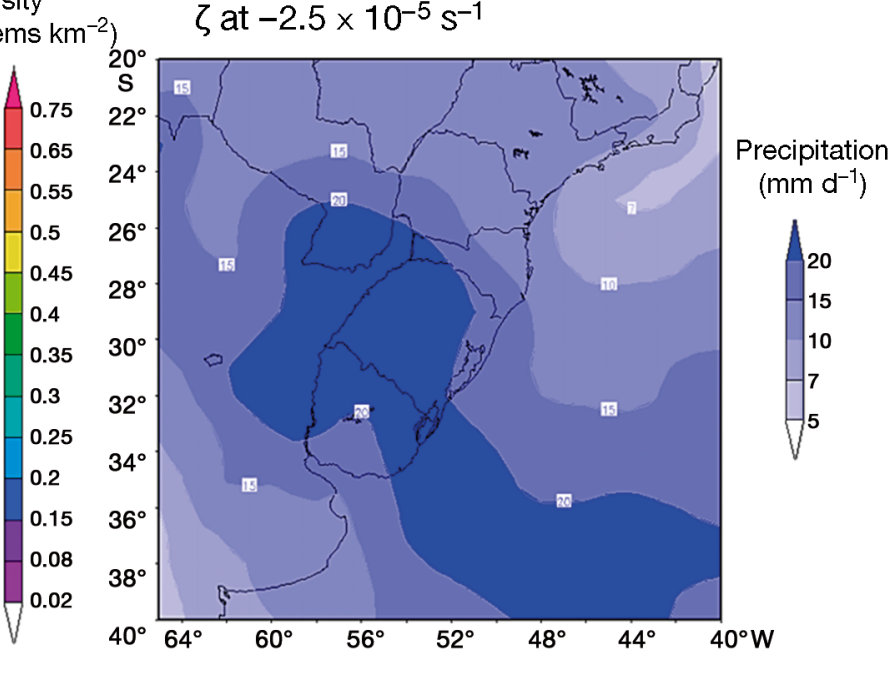

Fig. 5. (Left column) Annual density of cyclones related to the extreme precipitation events over LPB for 2 initial relative vorticity $\zeta$ thresholds: $(\mathrm{a}, \mathrm{b})-1.5 \times 10^{-5} \mathrm{~s}^{-1}$ and $(\mathrm{c}, \mathrm{d})-2.5 \times 10^{-5} \mathrm{~s}^{-1}$, using ERA-Interim reanalysis for the period 1989 to 2007 . (Right column) Composites of precipitation extremes (percentile 85) related to the density of cyclones for both vorticity thresholds. Figure adapted from Pereira (2013)

values lower than -1.0, which means that the precipitation departures from average conditions exceed 1 standard deviation). Moreover, drought occurrence in the LPB is high, with $>20$ drought events recorded during that period. These events have a mean duration of 3 to 6 mo, although extreme events can last for $>20$ mo. In terms of a drought hazard index (DHI; Shahid \& Behrawan 2008), most of the productive area of the LPB presents low to moderate drought hazard, while the western portion of the LPB shows a higher risk (Cavalcanti et al. 2015). Regarding trends, regionalized indices are shown in Fig. 6: dry periods (negative values of SPI) occurred during the 1960s in most of the regions, followed by decades with prevalence of humid periods. This result is in agreement with the trends in the annual number of dry days (Rivera et al. 2013) and with the negative trend in the percentage of stations with drought conditions (about $-3 \%$ every $10 \mathrm{yr}$ ) (Cavalcanti et al. 2015). An unprecedented increase in climate variability was observed during the last century in northeastern Argentina, shifting from dryness to wetness in decadal time steps (e.g. Piovano et al. 2002, Lovino et al. 2014). 

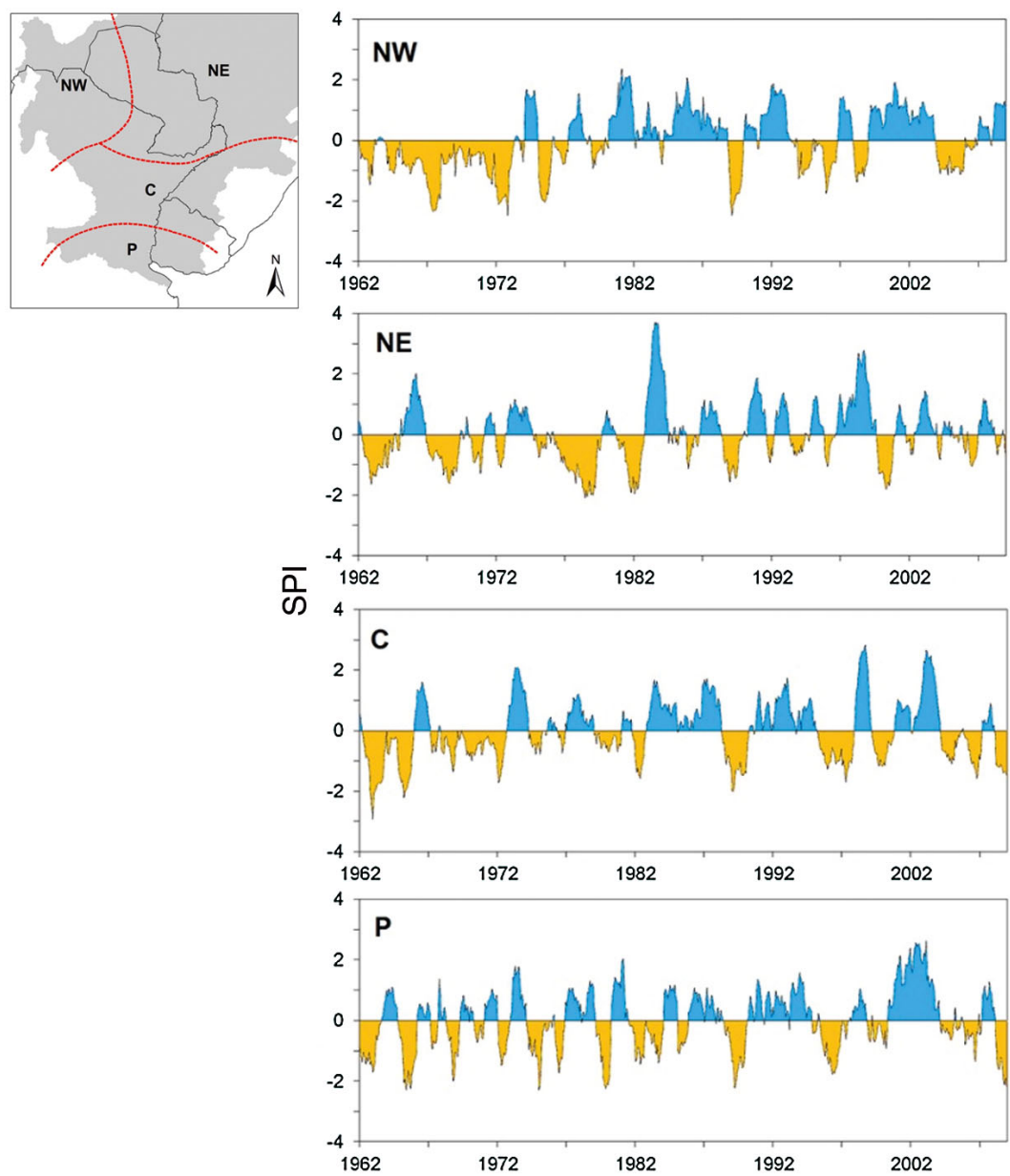

Fig. 6. Spatial regionalization of time series and the temporal evolution of the regional standardized precipitation index (SPI) patterns. Dashed red lines in the left panel separate the four climatic regions of the LPB (shaded): north-west $(\mathrm{NW})$, north-east (NE), central (C) and Pampas (P). The LPB region is shaded

In particular, precipitation extremes in the LPB are also related to these phenomena, some of which were studied during the project (see e.g. Grimm \& Tedeschi 2009, Barreiro 2010, Barreiro et al. 2014, Cavalcanti et al. 2015, Grimm et al. 2016, this Special). Typically, a low-pressure anomaly located on the southwest Atlantic off the coast of Patagonia, originating from Rossbywave activity, propagates northward, led by a cold front causing rainfall extremes in SESA through the uplifting of warmer air masses (Boers et al. 2014a). When the frontal system propagates northeastward through the LPB, the low-pressure anomaly merges with the Northwestern Argentinean Low, affecting the warm, moist low-level flow from the north reaching the LPB (Seluchi \& Saulo 2003, Arraut \& Barbosa 2009).

The most prominent summertime climate pattern in the LPB is the South American Monsoon System (SAMS; Zhou \& Lau 1998), in which climate variability at various timescales is associated with a dipole-like pattern with active nodes in the northern and southern LPB (e.g. Marengo et al. 2012 and references therein). The relationship between this dipole with rainfall extremes is discussed by Cavalcanti et al. (2015). As suggested in previous works (e.g. Silva \& Berbery 2006), the precipitation

\subsection{Remote forcings}

Precipitation anomalies in the LPB are influenced by teleconnections triggered by atmospheric circulation disturbances, which produce Rossby wave trains, connecting anomalous convection occurring in distant regions to anomalous conditions over the LPB (e.g. Berbery et al. 1992, Vera et al. 2004). The source regions for teleconnections are the anomalous warm pools in the tropical Pacific and Indian oceans (e.g. Grimm et al. 2000, Barros \& Silvestri 2002, Báez Benitez \& Monte Domecq 2014, Cherchi et al. 2014). In addition, precipitation anomalies in the LPB are influenced by mechanisms associated with SST anomalies in the tropical Atlantic (e.g. Diaz et al. 1998, Doyle \& Barros 2002, Berri \& Bertossa 2004, among others). Interdecadal precipitation variability is influenced by SST variations over all the oceans (Grimm \& Saboia 2015). extremes dipole is related to propagations of planetary wavetrains (Fig. 3 in Cavalcanti et al. 2015), and it is the most prominent mode of an oscillatory pattern that extends over the entire continent (Boers et al. 2014b).

The major source for the planetary wave propagation is located in the tropical Pacific Ocean, from where ENSO events influence the rainfall and extremes in the LPB, especially from October (0) through April (+1), with a small interruption in January $(+1)$ of El Niño episodes (Grimm \& Tedeschi 2009). The indexes (0) and (+) refer to the starting year of an episode and the following year, respectively. In November (0), the ENSO impact on the La Plata Basin is stronger than in other months, in terms of relative precipitation intensity, while in austral autumn (+), some of the strongest ENSO-related floods occurred in the basin. Nevertheless, each type of ENSO event (e.g. Ashok et al. 2007, Kao \& Yu 2009) 
is associated with anomalous tropospheric circulation in different regions (e.g. Larkin \& Harrison 2005, Hill et al. 2011). Tedeschi et al. (2013) showed that during the Canonical El Niño (La Niña) events, precipitation increases (decreases) are expected in the LPB during all seasons. Results on the frequency of extreme precipitation events are generally consistent with the behavior of total seasonal rainfall (Tedeschi et al. 2014). However, the areas affected by significant sensitivity in the frequency of extreme events are more extensive than those affected by significant sensitivity in the mean precipitation (i.e. there is more sensitivity to ENSO events in the extremes of the precipitation distribution; Grimm \& Tedeschi 2009). During ENSO Modoki events and during the austral spring, however, a dipole between the northern and southern LPB regions changes sign from El Niño to La Niña, indicating an increased (decreased) number of wet extremes in the southern (northern) LPB region during El Niño, and the opposite during La Niña (Fig. 4 in Cavalcanti et al. 2015).

Lastly, Robledo et al. (2013) focused on the role of the tropical oceans in modulating the intensity of extreme daily precipitation (DIER75 index; see Table 1) over the Argentinean sector of the LPB. Their results are in agreement with findings in the abovementioned studies. Niño3.4-like anomalies (warm tropical Atlantic anomalies) are related to enhanced (decreased) DIER75 index values year-round except in winter. In spring, the Indian Ocean Dipole Index (Saji et al. 1999) also plays a role favoring positive anomalies of DIER75. However, it should be highlighted that the relationship between the SST anomalies in tropical oceans and the DIER75 index in NE Argentina is modulated by decadal variations.

\subsection{Projections and uncertainties}

It is generally accepted that the range of validity of the physical parameterizations for an RCM depends on the region and the season (e.g. Seth \& Rojas 2003 for South America). Solman \& Pessacg (2012) evaluated the sensitivity of the MM5 RCM to several combinations of cumulus and planetary boundary layer parameterizations to simulate the frequency and intensity of extreme precipitation events during November-December 1986. This period was characterized by a clear see-saw pattern, associated with one of the main modes of intraseasonal variability over the region (Díaz \& Aceituno 2003). November 1986 was characterized by wet conditions and higher frequencies of moderate and heavy precipitation events compared to December 1986, when higher frequencies of occurrence of light precipitation events occurred. Although experiments were able to capture the main features of the intraseasonal variability, they overestimate the frequency of light precipitation events and underestimate the frequency of moderate rainy events. The heavy precipitation events were fairly well simulated. The authors found that the underestimation of rainfall is generally related to the underestimation of the amount of rainfall of individual rainy events, and concluded that improvements in the cumulus schemes are necessary to represent the intensity of rainfall more accurately.

In the climate change context, results from CLARISLPB RCMs nested into different GCMs under the SRES A1B emission scenario were documented by Sánchez et al. (2015), but focusing on the mean climate conditions (extremes were not considered). Based on daily defined indices, Sörensson et al. (2010a) explored the potential effects of climate change on the extreme rainfall events, using a single RCM (RCA3-E) nested into ECHAM5/MPI-OM GCM, forced by the A1B emission scenario. The extreme precipitation risks (defined as the probability of exceeding the present-day 95th percentile of precipitation) increased in the LPB during all seasons but spring. The increase in intense precipitation for the LPB is also reflected in the positive response of the maximum $5 \mathrm{~d}$ precipitation (Rx5day index; see Table 1). This index indicates the risk of flooding (Christensen \& Christensen 2003); therefore, its increase over the LPB of up to $50 \%$ probably implies a large impact for the late 21st century. Results presented by Sörensson et al. (2010a) suggest that seasonal precipitation and heavy rainfall events tend to increase by the end of this century, especially in the northern part of the LPB, although with no clear pattern of change for the dry spell duration (CDD index; see Table 1). In contrast, results by Zaninelli (2015), based on a subset of CLARIS-LPB RCMs, and applying a gridpoint- and model-dependent definition to determine dry spells, showed that the climate in the LPB is projected toward a wetter regime together with consistent changes in other measures of dryness (more frequent and shorter dry spells with respect to the present climate). Although this result is in agreement with findings by Menéndez et al. (2016), it must be taken with caution because RCMs still have inaccuracies simulating extremes in precipitation on both daily (Carril et al. 2012) and monthly scales (Menéndez et al. 2010a).

Projections made with coupled GCMs for the last period of the 21st century indicate a trend toward 
more frequent extreme (severe and moderate) wet months in the northern (southern) sector of the LPB and less frequent extreme and severe dry months. In particular, the impact of ENSO on extreme precipitation events in the LPB is projected to increase in the future (Cavalcanti et al. 2015).

Other authors have explored the future evolution of droughts. Results based on a CMIP5 multi-model ensemble forced by the RCP4.5 emission scenario
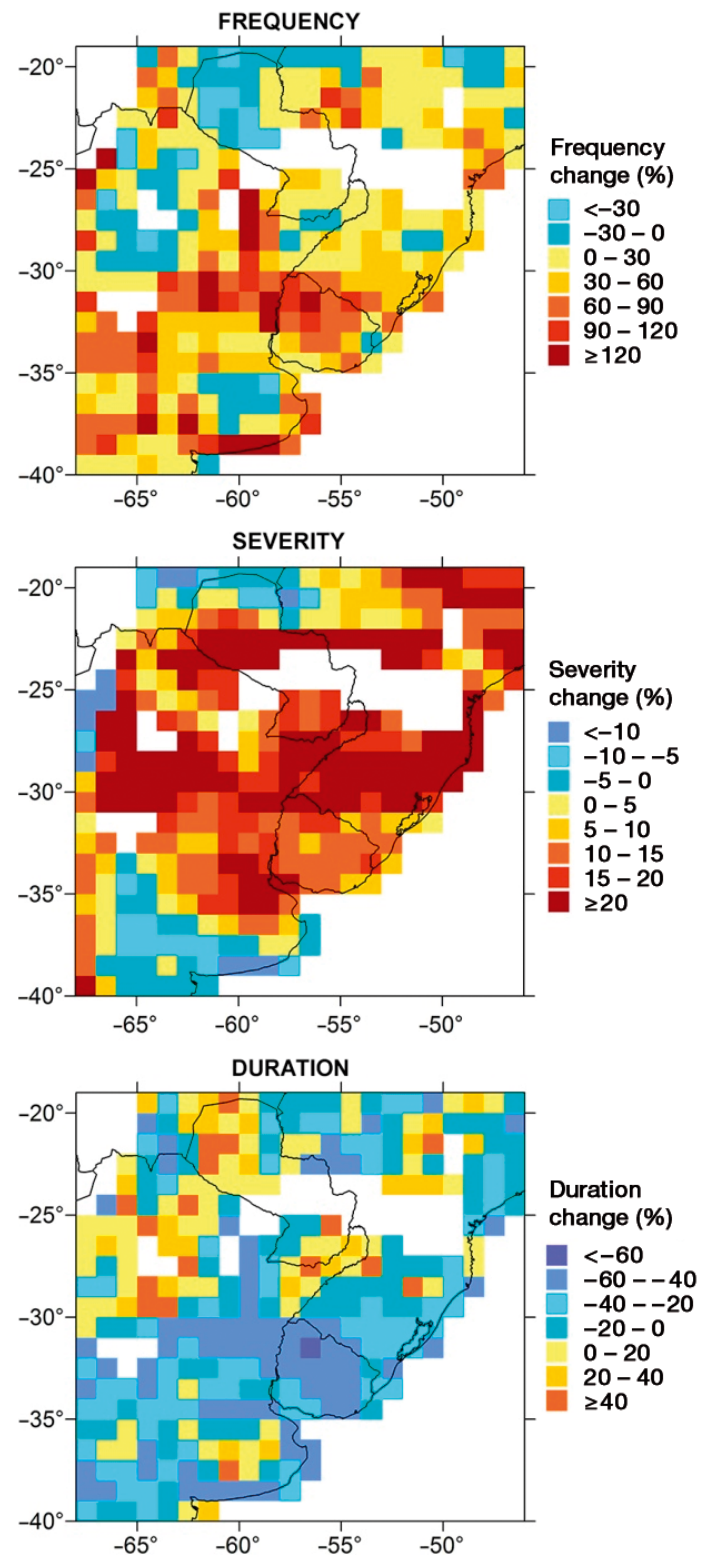

Fig. 7. Mean changes in long-term (12 mo) SPI drought characteristics projected by the multi-model ensemble for the period 2011-2040 relative to the 1979-2008 baseline along the RCP4.5 scenario. Severity is defined as the average SPI value during the drought events. The white areas over the continent indicate non-significant fits to the gamma probability distribution. Figure adapted from Penalba \& Rivera (2013)
(Fig. 7) indicate that in general, long-term droughts in the LPB will be more frequent in the medium-term future (2011-2040 with respect to the 1979-2008 period) but also shorter and more severe. Nevertheless, there are some specific areas where lower drought frequencies but longer durations are projected, such as north-western Argentina, western Paraguay and parts of eastern Argentina. Changes in the same sense are also documented for the distant future (2071-2100) and for a more extreme emission scenario (RCP8.5) (Penalba \& Rivera 2013).

\section{THE INFLUENCE OF LOCAL PROCESSES}

In addition to remote influences, local features can also contribute to the occurrence of extremes in the LPB. In that sense, the study of the soil moistureatmosphere interactions over the LPB is a relatively new issue. During the last decade, some studies have focused on the importance of soil moistureatmosphere interactions during the wet season of the SAMS (Fu \& Li 2004, Li \& Fu 2004, Grimm et al. 2007, Collini et al. 2008, Sörensson et al. 2010b, Barreiro \& Díaz 2011). These publications showed that the soil moisture state at the onset phase of the SAMS is important for the development of the monsoon. Koster et al. (2009b) suggested that the regions where soil moisture could influence precipitation are transition zones between dry and humid climates. The southern sector of the LPB (a region with high interannual variability of water content in the soil, located between the arid diagonal of South America [Garleff et al. 1991] and the humid region of southern Brazil) is a transition zone and, therefore, a relevant region for studying these phenomena. The coupling of soil moisture with precipitation (i.e. the quantitative effect of one variable on the other in a 1-way interaction) could be quantified as described by Sörensson \& Menéndez (2011). The coupling strength of soil moisture with precipitation was relatively high in the LPB (with values of memory larger than $20 \mathrm{~d}$ within part of the hot spot) during the onset and mature phase of the SAMS (see e.g. Sörensson et al. 2010b, Ruscica et al. 2014a). Humid areas, such as the Amazon, are not regions of high coupling between soil and rainfall because evapotranspiration is limited by the energy required to evaporate water (i.e. soil moisture is not a limiting factor).

These results motivated further studies on coupling strength and its relation to extreme events, realized within CLARIS-LPB. Sörensson \& Menéndez (2011) calculated the coupling strength index between soil 
moisture and both precipitation and evapotranspiration in austral summer (details of the index are in their section 3). The LPB was the most important hot spot of soil moisture-evapotranspiration (SM $\rightarrow$ ET) coupling in the continent, both in extension and magnitude (their Fig. 5). The soil moisture-precipitation coupling ( $\mathrm{SM} \rightarrow \mathrm{PP}$ ) was high in a smaller region within this hotspot, in the central part of the southern LPB (their Fig. 4). As a measure of extreme precipitation, the fraction of the 95th percentile rainfall contribution to total rainfall (Extreme Precipitation Index) was evaluated. The authors suggested that the interaction between soil moisture and atmospheric processes has some impact on this index over the LPB.

Regarding the memory of soil moisture over LPB in summer, model results by Ruscica et al. (2014a) indicated that regions with high $\mathrm{SM} \rightarrow$ ET coupling are characterized by low root-zone soil moisture memory (a few days). However, there are also smaller areas contained in the main hot spot in which memory and $\mathrm{SM} \rightarrow \mathrm{ET}$ and $\mathrm{SM} \rightarrow \mathrm{PP}$ couplings have relatively high values of coupling strength index (Fig. 8b in
Ruscica et al. 2014a). These results suggest that the soil-atmosphere interaction is a factor that can affect rainfall and contribute to their predictability in areas with high memory. However, the relationship between soil moisture and extreme precipitation events is not a priori evident. This issue clearly requires further investigation.

Moreover, Koster et al. (2009a) have shown that regions in which evaporation is controlled by soil moisture availability could experience drought-induced warming. Therefore, the LPB is one of the regions in the world where soil moisture-evaporation feedbacks could have an impact on heat waves. Preliminary results give evidence that soil moisture variability could be playing a role in modulating the temperature field. We highlight differences in daily TX probability distribution function (Fig. 8) between 2 samples: TX for all DJF and TX for dry DJF. The period considered is 1961-2000, and statistics of TX are estimated from TNCR. Seasonal precipitation is used as a proxy for the summertime soil moisture (see discussion in Section 3a in Koster et al. 2009b). Dry summers are
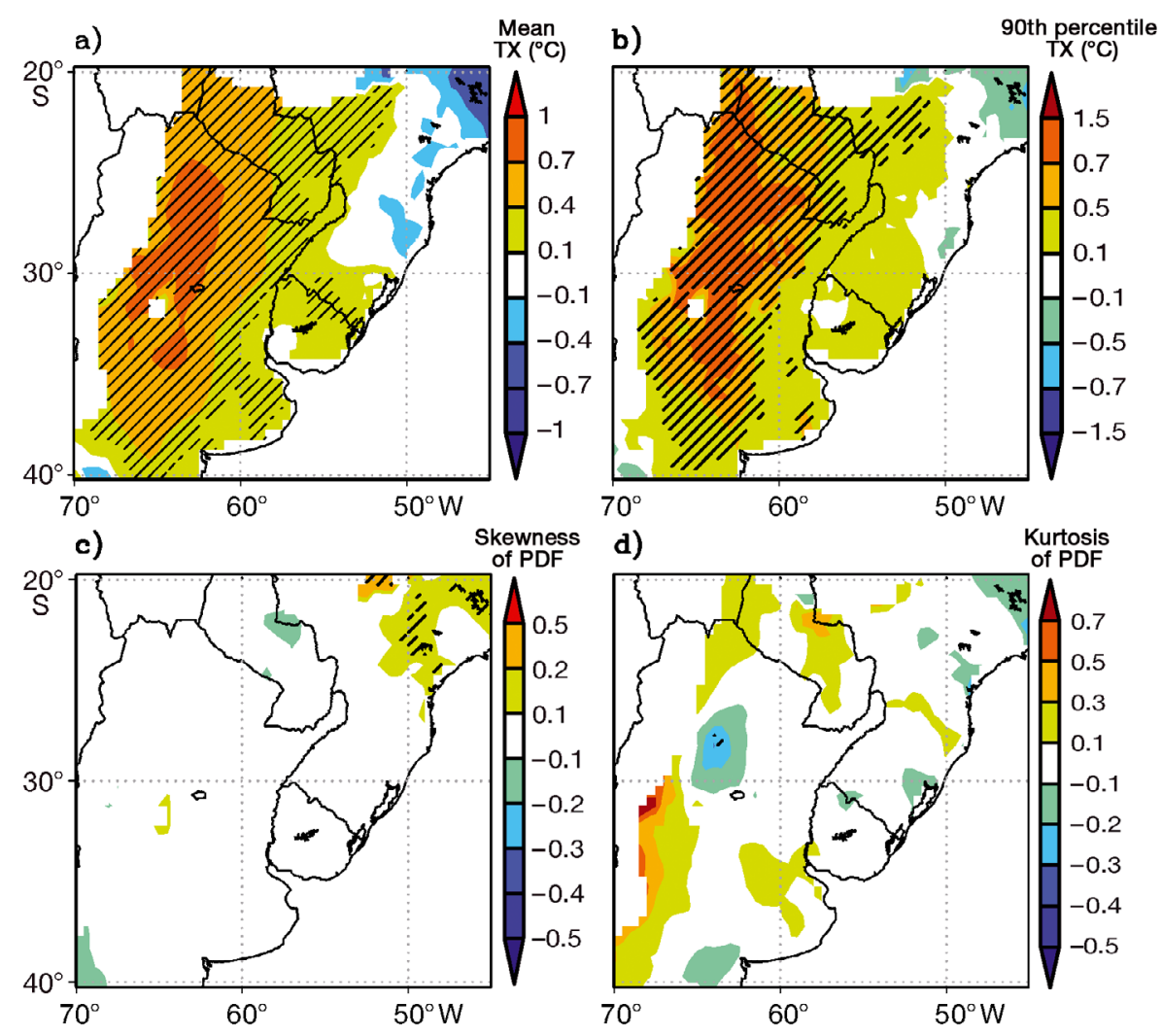

Fig. 8. Statistics estimated from 2 samples: TX DFJ and TX of 'dry' DJF. Top panels are for (a) the mean value and (b) the 90th percentile of TX. Bottom panels are for the (c) skewness and (d) kurtosis of the probability density function (PDF, dimensionless). Period is 1961-2000, and panels illustrate differences (statistics of TX minus statistics of TX dry summers). Striped areas indicate significant difference, according to the following test. For each grid point, the 2 distributions (TX from all years and TX from dry years) were concatenated, shuffled randomly, and redrawn 500 times; differences in those statistics were estimated to be significant when they were greater (lower) than the $95 \%(5 \%)$ quantile of the corresponding distribution of differences 
defined as those during which the SPI (precipitation accumulated during $3 \mathrm{mo}$ ) is $<-0.5$ (precipitation datasets from Jones et al. 2013). According to this definition, clusterization results in 18 dry summers. The top panels in Fig. 8 illustrate the leading-order impact of the summertime soil moisture variability in TX, in the sense that soil moisture-atmosphere interactions contribute to the variability in summertime surface temperature. Mean values of TX significantly increase during dry summers (Fig. 8a), with a hotspot in central-north Argentina and Paraguay, where TX exhibits large interannual variability (Zaninelli et al. 2015b). In contrast, mean values of TX appear to change only modestly over Uruguay (and over the south of Brazil where small cooling is also noted). Fig. 8b shows that the shift in mean values of TX over a vast region of LPB is associated with increases in the 90th percentile of TX. High-order moments further reveal that soil moisture dynamics have an impact on shifting the statistical distribution of TX toward higher values during dry summers but not on reshaping the probability distribution function (i.e. distributions do not manifest differences in either skewness or kurtosis; Fig. 8c,d). Although further research is still needed, preliminary results suggest that soil moisture-atmosphere interactions in the LPB do not particularly impact the tails of daily TX distribution, but influence both the mean values and the threshold of extremes in TX.

We know that land-use changes modulate the effects of large-scale variability locally (Pielke et al. 2011). Moreover, warming trends have sometimes been attributed to changes in land use, including the development of large cities, such as São Paulo and Rio de Janeiro (e.g. Marengo 2001, 2003). During the last decades, large areas in both the LPB and in the Argentinean Pampas have been extensively deforested; however, there are very few studies that address this topic (and none of them are related to extremes). During the project, the potential impacts of land-use changes over the LPB and the Argentinean Pampas were examined using model simulations forced by different idealized land-use scenarios representing agricultural expansion, reforestation and desertification. The results of Pessacg \& Solman (2012) showed significant warming and drying when forests are replaced by bare soils due to an increase in the net radiation budget and a reduction in the latent heat flux. However, the replacement of forests by crops resulted in a decrease in both the net radiation budget at surface and the latent and sensible heat fluxes, leading to significant cooling over central and eastern Argentina. Lastly, the modification of the actual land cover to crops produced a cooling and wetting over northern Argentina, Paraguay and parts of Bolivia due to a decrease in both the net radiation budget and the sensible heat flux and an increase in the latent heat flux.

\section{FUTURE CHALLENGES}

This paper reviews what we have learned during the CLARIS-LPB project regarding extremes in the LPB. The conceptual framework in which extremes are embedded is basically given by ocean-soilatmosphere interactions and their variabilities at different timescales. That is, extremes are the result of multiple interactions, including regional processes and remote forcings. Regarding the regional processes, we highlighted soil moisture-atmosphere interactions, the impact of the land use and the extratropical systems. Tropical and extratropical oceans force regional anomalies and atmospheric largescale circulation patterns, and could leave imprints in regional variability (see e.g. Barreiro 2010). Moreover, forcing sources are affected by variability on several time scales (including low-frequency modulation), which is then transferred to regional scales, affecting extremes.

Despite the significant progress that was made on describing and understanding extremes, many challenges remain, and some gaps have been identified. At regional scales, additional efforts to better understand the link between soil characteristics and the atmosphere are needed (e.g. Ruscica et al. 2014b, Menéndez et al. 2016), and a gap was found in studies that relate extremes with changes in land use. Further research on the relationship between the development of cut-off lows and the occurrence of extreme precipitation events is also needed (Godoy et al. 2011). In addition, trends and variability in the diurnal cycle of precipitation, with implications for the frequency of occurrence and intensity of extremes in the LPB, need to be studied. This research will be challenging because both models and reanalysis had deficiencies with regard to appropriately representing the diurnal cycle of precipitation. At the hemispheric scale, focus should be on improved description and understanding of the role that the boundary forcing parameters play (ocean and land) and on the large-scale circulation patterns. The relative importance of the regional feedbacks (including hotspots of coupling strength) versus the large-scale forcings (including seasonal predictability sources) is still largely unknown. Efforts in that 
sense could potentially improve seasonal forecasts of extremes and the implementation of operational early warning systems for agricultural applications.

Some specific research questions that need further investigation include the following: (1) What are the relative roles of local versus remote forcings in the occurrence of extremes (SST, land surface and topography)? Several studies have shown the role of teleconnections and local forcings with regard to extreme precipitation over the LPB, as mentioned in the 'Introduction'. However, the relative role of large-scale versus local forcings has not yet been analyzed. (2) What is the effect of land use on amplifying/decreasing extremes? This is a very important problem to be analyzed in face of Amazon deforestation. There are several studies of land-use effects on precipitation of the region, but there are not studies on such effects over the LPB. (3) What is the role of the interaction processes between the land surface and the atmosphere with regard to precipitation and temperature extremes? The feedbacks related to soil moisture, the memory in the system introduced by its anomalies, and related features such as surface inhomogeneities can influence different types of extremes on different scales (e.g. heat waves, daily precipitation events, etc.). (4) How will extreme events evolve in the future? Several studies have been performed regarding extremes in future projections. However, with global and regional model developments, this projection is an issue that needs continuous analysis. (5) What are the uncertainties in extreme climate change projections? This uncertainty is another issue that deserves continuous analysis, because the models are improving, and it is expected that the uncertainties will be reduced in the new-generation models. Obstacles that may affect progress toward answering questions mainly include (1) the lack of high-resolution and high-frequency data, and (2) the current state of the art of models and parameterizations. Combining an intensive monitoring and modeling strategy should be considered a challenge for the regional community. Improvements in monitoring and modeling will also result in reduced uncertainties and increased confidence in regional climate change projections.

Finally, we have noticed that recent research efforts are mainly focused on a better description and understanding of extremes in temperature and precipitation. On one hand, we know that a vast area on the northern coast of Buenos Aires province (including Buenos Aires City and surrounding areas) is periodically affected by storm surges in the Río de la Plata estuary (Escobar et al. 2004), flooding the pop- ulated coast. There is a need for further research on winds and wind-wave extremes (Dragani et al. 2013a,b) (which were not addressed at all in CLARISLPB) to move toward an integrated forecast system of the interface Rio de la Plata-atmosphere. On the other hand, we have noticed that attribution of extreme events to the emissions of greenhouse gases from anthropogenic sources (Stott et al. 2013) has been little explored in the LPB (Hannart et al. 2015). Among the limitations to develop this research line in the LPB, we highlight (1) the state-of-knowledge of physical causes of extremes and how extremes may link to anthropogenic emissions and (2) the reliability of the simulations to capture both the extreme events and the real-world predictability (e.g. Seneviratne et al. 2012, Peterson et al. 2012).

Acknowledgements. This work was supported by the European Community's Seventh Framework Programme (CLARISLPB, Grant Agreement No. 212492), by the Argentinean agencies CONICET (PIP 112-201101-00932) and ANPCYT (PICT-2014-0887) and by the French National Programme LEFE/INSU (AO 2015-876370). T.A. also thanks the partial support from FAPESP (08/58101-9), CNPq and ITV (Institute Vale of Technology).

\section{LITERATURE CITED}

Alessandro AP (1998) Aspectos sinópticos de las intensas lluvias del verano 1982-1983. Meteorologica 23:3-14

Alessandro AP, Lichtenstein E (1996) Situación sinóptica asociada a la sequía del invierno de 1995. Rev Geofis 45: 125-143

Alexander LV, Zhang X, Peterson TC, Caesar J and others (2006) Global observed changes in daily climate extremes of temperature and precipitation. J Geophys Res D 111:D05109, doi:10.1029/2005JD006290

Arraut JM, Barbosa HMJ (2009) Large scale features associated with strong frontogenesis in equivalent potential temperature in the South American subtropics east of the Andes. Adv Geosci 22:73-78

> Ashok K, Behera SK, Rao SA, Weng H, Yamagata T (2007) El Niño Modoki and its possible teleconnection. J Geophys Res C112:C11007, doi:10.1029/2006JC003798

Báez Benitez J, Monte Domecq R (2014) Analysis of meteorological drought episodes in Paraguay. Clim Change 127:15-25

Barreiro M (2010) Influence of ENSO and the South Atlantic Ocean on climate predictability over Southeastern South America. Clim Dyn 35:1493-1508

Barreiro M, Díaz N (2011) Land-atmosphere coupling in El Niño influence over South America. Atmos Sci Lett 12: 351-355

Barreiro M, Díaz N, Renom M (2014) Role of the global oceans and land-atmosphere interaction on summertime interdecadal variability over northern Argentina. Clim Dyn 42:1733-1753

Barros VR, Silvestri GE (2002) The relationship between sea surface temperature at the subtropical south-central 
Pacific and precipitation in southeastern South America. J Clim 15:251-267

Barros VR, Grimm AM, Doyle ME (2002) Relationship between temperature and circulation in Southeastern South America and its influence from El Niño and La Niña events. J Meteorol Soc Jpn 80:21-32

Barrucand M, Rusticucci M (2001) Climatología de temperaturas extremas en la Argentina: variabilidad temporal y regional. Meteorologica 26:85-101

> Barrucand MG, Vargas WM, Rusticucci MM (2007) Dry conditions over Argentina and the related monthly circulation patterns. Meteorol Atmos Phys 98:99-114

> Barrucand M, Vargas W, Bettolli ML (2014) Warm and cold dry months and associated circulation in the humid and semi-humid Argentine region. Meteorol Atmos Phys 123: 143-154

> Berbery EH, Barros VR (2002) The hydrologic cycle of the La Plata basin in South America. J Hydrometeorol 3: 630-645

> Berbery EH, Nogues-Paegle J, Horel JD (1992) Wavelike Southern Hemisphere extratropical teleconnections. J Atmos Sci 49:155-157

> Berri GJ, Bertossa GI (2004) The influence of the tropical and subtropical Atlantic and Pacific Oceans on precipitation variability over southern central South America on seasonal time scales. Int J Climatol 24:415-435

- Bettolli ML, Penalba OC (2014) Synoptic sea level pressure patterns-daily rainfall relationship over the Argentine Pampas in a multi-model simulation. Meteorol Appl 21: 376-383

Bischoff SA, Vargas WM (2006) Climatic properties of the daily $500 \mathrm{hPa}$ circulation ECWMF reanalysis data over southern South America during 1980-1988. Meteorologica 23:3-12

Boers N, Bookhagen B, Barbosa HMJ, Marwan N, Kurths J, Marengo JA (2014a) Prediction of extreme floods in the eastern Central Andes based on a complex networks approach. Nat Commun 5:5199

Boers N, Rheinwalt A, Bookhagen B, Barbosa HMJ, Marwan N, Marengo J, Kurths J (2014b) The South American rainfall dipole: a complex network analysis of extreme events. Geophys Res Lett 41:7397-7405

> Boers N, Bookhagen B, Marengo J, Marwan N, von Storch JS, Kurths J (2015) extreme rainfall of the South American monsoon system: a dataset comparison using complex networks. J Clim 28:1031-1056

> Boulanger JP, Brasseur G, Carril AF, de Castro M and others (2010) A Europe-South America network for climate change assessment and impact studies. Clim Change 98: 307-329

> Camilloni IA, Barros VR (2003) Extreme discharge events in the Paraná River and their climate forcing. J Hydrol (Amst) 278:94-106

Carril AF, Menéndez CG, Remedio ARC, Robledo F and others (2012) Performance of a multi-RCM ensemble for South Eastern South America. Clim Dyn 39:2747-2768

Carvalho LMV, Jones C, Liebmann B (2002) Extreme precipitation events in southeastern South America and large-scale convective patterns in the South Atlantic covergence zone. J Clim 15:2377-2394

> Carvalho LMV, Jones C, Liebmann B (2004) The South Atlantic convergence zone: Intensity, form, persistence, and relationships with intraseasonal to interannual activity and extreme rainfall. J Clim 17:88-108

Cavalcanti IFA (2012) Large scale and synoptic features associated with extreme precipitation over South America: a review and case studies for the first decade of the 21st century. Atmos Res 118:27-40

Cavalcanti IFA, Carril AF, Penalba OC, Grimm AM and others (2015) Precipitation extremes over La Plata Basinreview and new results from observations and climate simulations. J Hydrol (Amst) 523:211-230

Cavalcanti IFA, Müller GV, Andrade KM, Fernández Long ME (2013) Cold air intrusions over southeastern South America-GFDL model behavior regarding climate simulations in the 20th century and future projections. Global Planet Change 111:31-42

Cerne SB, Vera CS (2011) Influence of the intraseasonal variability on heat waves in subtropical South America. Clim Dyn 36:2265-2277

Cerne SB, Vera CS, Liebmann B (2007) The nature of a heat wave in eastern Argentina occurring during SALLJEX. Mon Weather Rev 135:1165-1174

Chaves RR, Cavalcanti IFA (2001) Atmospheric circulation features associated with rainfall variability over southern northeast Brazil. Mon Weather Rev 129:2614-2626

Cherchi A, Carril AF, Menéndez CG, Zamboni L (2014) La Plata basin precipitation variability in spring: role of remote SST forcing as simulated by GCM experiments. Clim Dyn 42:219-236

Christensen JH, Hewitson B, Busuioc C, Chen A and others (2007) Climate change 2007: the physical science basis. Regional climate projections. Contribution of Working Group I to the Fourth Assessment Report of the Intergovernmental Panel on Climate Change. Cambridge University Press, Cambridge, p 847-940

Christensen JH, Christensen OB (2003) Climate modelling: severe summertime flooding in Europe. Nature 421: 805-806

Collini EA, Berbery EH, Barros VR, Pyle ME (2008) How does soil moisture influence the early stages of the South American monsoon? J Clim 21:195-213

> Compo GP, Whitaker JS, Sardeshmukh PD, Matsui N and others (2011) The Twentieth Century Reanalysis project. Q J R Meteorol Soc 137:1-28

> Díaz A, Aceituno P (2003) Atmospheric circulation anomalies during episodes of enhanced and reduced convective cloudiness over Uruguay. J Clim 16:3171-3185

Diaz AF, Studzinski CD, Mechoso CR (1998) Relationships between precipitation anomalies in Uruguay and southern Brazil and sea surface temperature in the Pacific and Atlantic oceans. J Clim 11:251-271

Donat MG, Alexander LV, Yang H, Durre I and others (2013) Updated analyses of temperature and precipitation extreme indices since the beginning of the twentieth century: the HadEX2 dataset. J Geophys Res D 118: 2098-2118

> Doyle ME, Barros VR (2002) Midsummer low-level circulation and precipitation in subtropical South America and related sea surface temperature anomalies in the South Atlantic. J Clim 15:3394-3410

Dragani WC, D'Onofrio EE, Oreiro F, Alonso G, Fiore M, Grismeyer W (2013b) Simultaneous meteorological tsunamis and storm surges at Buenos Aires coast, southeastern South America. Nat Hazards 74:269-280

> Dragani WC, Cerne BS, Campetella CM, Possia NE, Campos MI (2013a) Synoptic patterns associated with the highest wind-waves at the mouth of the Río de la Plata estuary. Dyn Atmos Oceans 61-62:1-13

Escobar G, Vargas W, Bischoff S (2004) Wind tides in the Rio 
de la Plata estuary: meteorological conditions. Int J Climatol 24:1159-1169

> Fernández-Long ME, Müller GV, Beltrán-Przekurat A, Scarpati OE (2013) Long-term and recent changes in temperature-based agroclimatic indices in Argentina. Int J Climatol 33:1673-1686

Fu R, Li W (2004) The influence of the land surface on the transition from dry to wet season in Amazonia. Theor Appl Climatol 78:97-110

Garleff K, Schabitz F, Stingl H, Veit H (1991) Jungquartäre Landschaftsentwicklung und Klimageschichte beiderseits der Ariden Diagonale Südamerikas. Bamberger Geogr Schr 11:359-394

Garreaud RD (1999) Cold air incursions over subtropical and tropical South America: a numerical case study. Mon Weather Rev 127:2823-2853

Garreaud RD (2000) Cold air incursions over subtropical South America: mean structure and dynamics. Mon Weather Rev 128:2544-2559

> Godoy AA, Campetella CM, Possia NE (2011) Un caso de baja segregada en niveles altos en el sur de Sudamérica: descripción del ciclo de vida y su relación con la precipitación. Rev Brasil Meteorol 26:491-502

Grimm AM, Saboia JPJ (2015) Interdecadal variability of the South American precipitation in the monsoon season. J Clim 28:755-775

> Grimm AM, Tedeschi RG (2009) ENSO and extreme rainfall events in South America. J Clim 22:1589-1609

Grimm AM, Barros VR, Doyle ME (2000) Climate variability in southern South America associated with El Nino and La Nina events. J Clim 13:35-58

> Grimm AM, Pal J, Giorgi F (2007) Connection between spring conditions and peak summer monsoon rainfall in South America: role of soil moisture, surface temperature, and topography in eastern Brazil. J Clim 20: 5929-5945

> Grimm AM, Laureanti NC, Rodakoviski RB, Gama CB (2016) Interdecadal variability and extreme precipitation events in South America during the monsoon season. Clim Res 68:277-294

> Groisman PY, Knight RW, Easterling DR, Karl TR, Hegerl GC, Razuvaev VN (2005) Trends in intense precipitation in the climate record. J Clim 18:1326-1350

Hannart A, Vera C, Otto FEL, Cerne B (2015) Causal influence of anthropogenic forcings on the Argentinian heat wave of December 2013. Bull Am Meteorol Soc 96: $\mathrm{S} 41-\mathrm{S} 45$

> Haylock MR, Peterson TC, Alves LM, Ambrizzi T and others (2006) Trends in total and extreme South American rainfall in 1960-2000 and links with sea surface temperature. J Clim 19:1490-1512

Hill KJ, Taschetto AS, England MH (2011) Sensitivity of South American summer rainfall to tropical Pacific Ocean SST anomalies. Geophys Res Lett 38:L01701, doi: 10.1029/2010GL045571

> Hoskins BJ, Hodges KI (2005) A new perspective on Southern Hemisphere storm tracks. J Clim 18:4108-4129

> Jones PD, Lister DH, Harpham C, Rusticucci M, Penalba O (2013) Construction of a daily precipitation grid for southeastern South America for the period 1961-2000. Int J Climatol 33:2508-2519

> Junquas C, Vera C, Li L, Le Treut H (2012) Summer precipitation variability over Southeastern South America in a global warming scenario. Clim Dyn 38:1867-1883

Kalnay E, Kanamitsu M, Kistler R, Collins W and others
(1996) The NCEP/NCAR 40-year reanalysis project. Bull Am Meteorol Soc 77:437-471

Kao HY, Yu JY (2009) Contrasting Eastern-Pacific and Central-Pacific types of ENSO. J Clim 22:615-632

> Kendon EJ, Rowell DP, Jones RG, Buonomo E (2008) Robustness of future changes in local precipitation extremes. J Clim 21:4280-4297

Koster RD, Schubert SD, Suarez MJ (2009a) Analyzing the concurrence of meteorological droughts and warm periods, with implications for the determination of evaporative regime. J Clim 22:3331-3341

> Koster RD, Wang H, Schubert SD, Suarez MJ, Mahanama S (2009b) Drought-induced warming in the continental United States under different SST regimes. J Clim 22: 5385-5400

Labraga JC, Scian B, Frumento O (2002) Anomalies in the atmospheric circulation associated with the rainfall excess or deficit in the Pampa Region in Argentina. J Geophys Res D 107:4666, doi:10.1029/2002JD002113

> Larkin NK, Harrison DE (2005) Global seasonal temperature and precipitation anomalies during El Niño autumn and winter. Geophys Res Lett 32:L16705, doi:10.1029/2005 GL022860

Li W, Fu R (2004) Transition of the large-scale atmospheric and land surface conditions from the dry to the wet season over Amazonia as diagnosed by the ECMWF re-analysis. J Clim 17:2637-2651

Lopez-Franca N, Zaninelli P, Carril AF, Menéndez CG, Sánchez E (2016) Changes in temperature extremes for 21st century scenarios over South America derived from a multi-model ensemble of regional climate models. Clim Res 68:151-167

> Lovino M, García NO, Baethgen W (2014) Spatiotemporal analysis of extreme precipitation events in the Northeast region of Argentina (NEA). J Hydrol Reg Stud 2:140-158

Marengo J (2001) Mudanças climáticas globais e regionais: Avaliação do clima atual do Brasil e projeções de cenários climáticos do futuro. Rev Bras Meteor 16:1-18

Marengo J (2003) Condições climáticas e recursos hídricos no Norte Brasileiro. In: Tucci CE, Braga B (eds) Clima e recursos hídricos no Brasil. Associação Brasileira de Recursos Hídricos FBMC/ANA, p 117-161

- Marengo JA, Jones R, Alves LM, Valverde MC (2009) Future change of temperature and precipitation extremes in South America as derived from the PRECIS regional climate modeling system. Int J Climatol 29: 2241-2255

Marengo JA, Ambrizzi T, da Rocha RP, Alves LM and others (2010a) Future change of climate in South America in the late twenty-first century: intercomparison of scenarios from three regional climate models. Clim Dyn 35: 1073-1097

> Marengo JA, Rusticucci M, Penalba O, Renom M (2010b) An intercomparison of observed and simulated extreme rainfall and temperature events during the last half of the twentieth century. 2. Historical trends. Clim Change 98: 509-529

> Marengo JA, Liebmann B, Grimm AM, Misra V and others (2012) Recent developments on the South American monsoon system. Int J Climatol 32:1-21

McKee TB, Doesken NJ, Kleist J (1993) The relationship of drought frequency and duration to time scales. Eighth Conference on Applied Climatology, 17-22 January, 1993. American Meteorological Society, Anaheim, CA, p 179-184 
Menéndez CG, de Castro M, Boulanger JP, D'Onofrio A and others (2010a) Downscaling extreme month-long anomalies in southern South America. Clim Change 98: 379-403

> Menéndez CG, Carril AF (2010) Potential changes in extremes and links with the Southern Annular Mode as simulated by a multi-model ensemble. Clim Change 98: 359-377

Menéndez CG, De Castro M, Sörensson A, Boulanger JP (2010b) CLARIS project: towards climate downscaling in South America. Meteorol Z 19:357-362

Menéndez CG, Zaninelli PG, Carril AF, Sánchez E (2016) Hydrological cycle, temperature and land surface-atmosphere interaction in the La Plata Basin during summer: response to climate change. Clim Res 68:231-241

Minetti JL, Vargas WM, Vega B, Costa MC (2007) Las sequías en la pampa húmeda: impacto en la productidad del maíz. Rev Brasil Meteorol 22:218-232

Müller GV (2007) Patterns leading to extreme events in Argentina: partial and generalized frosts. Int J Climatol 27:1373-1387

Müller GV, Ambrizzi T (2007) Teleconnection patterns and Rossby wave propagation associated to generalized frosts over southern South America. Clim Dyn 29: 633-645

Müller GV, Ambrizzi T (2010) Rossby wave propagation tracks in southern hemisphere mean basic flows associated to generalized frosts over southern South America. Atmósfera 23:25-35

Müller GV, Berri GJ (2007) Atmospheric circulation associated with persistent generalized frosts in Central-Southern South America. Mon Weather Rev 135:1268-1289

Müller GV, Berri GJ (2012) Atmospheric circulation associated with extreme generalized frosts persistence in central-southern South America. Clim Dyn 38:837-857

Müller GV, Nuñez MN, Seluchi ME (2000) Relationship between ENSO cycles and frost events within the Pampa Humeda region. Int J Climatol 20:1619-1637

Naumann G, Vargas WM (2010) Joint diagnostic of the surface air temperature in southern South America and the Madden-Julian oscillation. Weather Forecast 25: 1275-1280

Penalba OC, Bettolli ML (2011) Climate change impacts on atmospheric circulation and daily precipitation in the Argentine Pampas region. In: Blanco J, Kheradmand $\mathrm{H}$ (eds) Climate change-geophysical foundations and ecological effects. InTech, Rijeka, p 137-156

> Penalba OC, Rivera JA (2013) Future changes in drought characteristics over southern South America projected by a CMIP5 multi-model ensemble. Am J Clim Chang 2: 173-182

Penalba OC, Rivera JA (2015) Comparación de seis índices para el monitoreo de sequías meteorológicas en el sur de Sudamérica. Meteorologica 40:33-57

> Penalba OC, Robledo FA (2010) Spatial and temporal variability of the frequency of extreme daily rainfall regime in the La Plata Basin during the 20th century. Clim Change 98:531-550

Penalba OC, Rivera JA, Pántano VC (2014) The CLARIS LPB database: constructing a long-term daily hydrometeorological dataset for La Plata Basin, Southern South America. Geosci Data J 1:20-29

Pereira N (2013) Impacts of extratropical cyclones on extreme precipitation events over the La Plata Basin. MSc thesis, University of São Pablo
Pessacg NL, Solman S (2012) Effects of land-use changes on climate in southern South America. Clim Res 55:33-51

Peterson TC, Stott PA, Herring S (2012) Explaining extreme events of 2011 from a climate perspective. Bull Am Meteorol Soc 93:1041-1067

Pielke RA, Pitman A, Niyogi D, Mahmood R and others (2011) Land use/land cover changes and climate: modeling analysis and observational evidence. Wiley Interdiscip Rev Clim Chang 2:828-850

$>$ Piovano EL, Ariztegui D, Damatto Moreira S (2002) Recent environmental changes in Laguna Mar Chiquita (central Argentina): a sedimentary model for a highly variable saline lake. Sedimentology 49:1371-1384

Re M, Barros V, Saurral R (2006) Extreme precipitation in Argentina. International Conference on Southern Hemisphere Meteorology and Oceanography (ICSHMO), 8, Foz do Iguaçu, p 1575-1583

> Reboita M, da Rocha R, Ambrizzi T, Sugahara S (2010) South Atlantic Ocean cyclogenesis climatology simulated by regional climate model (RegCM3). Clim Dyn 35: 1331-1347

Renom M (2009) Temperaturas extremas en Uruguay: análisis de la variabilidad temporal de baja frecuencia y su relación con la circulación de gran escala. PhD dissertation, University of Buenos Aires

Renom M, Rusticucci M, Barreiro M (2011) Multidecadal changes in the relationship between extreme temperature events in Uruguay and the general atmospheric circulation. Clim Dyn 37:2471-2480

Renom M, De Mello S, Badagian J (2014) Extreme temperature events: summer heat waves and frost days in Uruguay-Southeastern South America, observed changes during 1950-2009. American Meteorological Society 94th Annual Meeting, Atlanta, GA

Rivera JA, Penalba OC, Betolli ML (2013) Inter-annual and inter-decadal variability of dry days in Argentina. Int $\mathrm{J}$ Climatol 33:834-842

Roads J, Chen S, Cocke S, Druyan L and others (2003) International Research Institute/Applied Research Centers (IRI/ARCs) regional model intercomparison over South America. J Geophys Res D 108:4425, doi:10.1029/2002 JD003201

Robledo FA, Penalba OC, Bettolli ML (2013) Teleconnections between tropical-extratropical oceans and the daily intensity of extreme rainfall over Argentina. Int J Climatol 33:735-745

Ruscica RC, Sörensson AA, Menéndez CG (2014a) Hydrological links in Southeastern South America: soil moisture memory and coupling within a hot spot. Int J Climatol 34:3641-3653

Ruscica RC, Sörensson AA, Menéndez CG (2014b) Pathways between soil moisture and precipitation in southeastern South America. Atmos Sci Lett 16:267-272

Rusticucci M (2012) Observed and simulated variability of extreme temperature events over South America. Atmos Res 106:1-17

Rusticucci M, Barrucand M (2004) Observed trends and changes in temperature extremes over Argentina. J Clim 17:4099-4107

Rusticucci MM, Kousky VE (2002) A comparative study of maximum and minimum temperatures over Argentina: NCEP-NCAR reanalysis versus station data. J Clim 15: 2089-2101

Rusticucci M, Tencer B (2008) Observed changes in return values of annual temperature extremes over Argentina. 
J Clim 21:5455-5467

Rusticucci M, Vargas W (1995a) Seasonal and diurnal patterns of dry- and wet-bulb temperatures over Argentina. Int J Climatol 15:1273-1282

Rusticucci M, Vargas W (1995b) Synoptic situations related to spells of extreme temperatures over Argentina. Meteorol Appl 2:291-300

Rusticucci MM, Vargas WM (2001) Interannual variability of temperature spells over Argentina. Atmósfera 14: 75-86

Rusticucci M, Vargas W (2002) Cold and warm events over Argentina and their relationship with the ENSO phases: risk evaluation analysis. Int J Climatol 22:467-483

Rusticucci MM, Venegas SA, Vargas WM (2003) Warm and cold events in Argentina and their relationship with South Atlantic and South Pacific Sea surface temperatures. J Geophys Res C 108:20-21

> Rusticucci M, Marengo J, Penalba O, Renom M (2010) An intercomparison of model-simulated in extreme rainfall and temperature events during the last half of the twentieth century. 1. Mean values and variability. Clim Chang 98:493-508

Saji NH, Goswami BN, Vinayachandran PN, Yamagata T (1999) A dipole mode in the tropical Indian Ocean. Nature 401:360-363

Sánchez E, Solman S, Remedio ARC, Berbery H and others (2015) Regional climate modelling in CLARIS-LPB: a concerted approach towards twentyfirst century projections of regional temperature and precipitation over South America. Clim Dyn 45:2193-2212

Sansigolo CA, Kayano MT (2010) Trends of seasonal maximum and minimum temperatures and precipitation in Southern Brazil for the 1913-2006 period. Theor Appl Climatol 101:209-216

Scian B, Donnari M (1997) Retrospective analysis of the Palmer Drought Severity Index in the semi-arid Pampas region, Argentina. Int J Climatol 17:313-322

Seluchi ME, Marengo JA (2000) Tropical-midlatitude exchange of air masses during summer and winter in South America: climatic aspects and examples of intense events. Int J Climatol 20:1167-1190

Seluchi M, Saulo A (2003) The northwestern Argentinean low: a study of two typical events. Mon Weather Rev 131: 2361-2378

Seneviratne SI, Nicholis N, Easterling D, Goodess CM and others (2012) Changes in climate extremes and their impacts on the natural physical environment. In: Field CB, Barros V, Stocker TF, Qin D and others (eds) Managing the risks of extreme events and disasters to advance climate change adaptation. A Special Report of Working Groups I and II of the Intergovernmental Panel on Climate Change (IPCC). Cambridge University Press, Cambridge and New York, NY, p 109-230

Serio L, Martin P, Murphy GM (2010) Evaluación de una metodología de pronóstico estadístico para la condición hídrica del suelo en la región pampeana argentina. Agriscientia 27:11-17

Seth A, Rojas M (2003) Simulation and sensitivity in a nested modeling system for South America. I. Reanalyses boundary forcing. J Clim 16:2437-2453

> Shahid S, Behrawan H (2008) Drought risk assessment in the western part of Bangladesh. Nat Hazards 46:391-413

> Silva VBS, Berbery EH (2006) Intense rainfall events affecting the La Plata Basin. J Hydrometeorol 7:769-787

Simmonds I, Keay K (2000a) Mean Southern Hemisphere extratropical cyclone behavior in the 40-year NCEPNCAR reanalysis. J Clim 13:873-885

Simmonds I, Keay K (2000b) Variability of Southern Hemisphere extratropical cyclone behavior, 1958-97. J Clim 13:550-561

Sinclair MR (1994) An objective cyclone climatology for the Southern Hemisphere. Mon Weather Rev 122:2239-2256

Sinclair MR (1995) A climatology of cyclogenesis for the Southern Hemisphere. Mon Weather Rev 123:1601-1619

> Sinclair MR (1997) Objective identification of cyclones and their circulation intensity, and climatology. Weather Forecast 12:595-612

> Solman SA, Sanchez E, Samuelsson P, de Rocha RP and others (2013) Evaluation of an ensemble of regional climate model simulations over South America driven by the ERA-Interim reanalysis: model performance and uncertainties. Clim Dyn 41:1139-1157

Solman SA, Menéndez CG (2003) Weather regimes in the South American sector and neighbouring oceans during winter. Clim Dyn 21:91-104

Solman SA, Pessacg NL (2012) Regional climate simulations over South America: sensitivity to model physics and to the treatment of lateral boundary conditions using the MM5 model. Clim Dyn 38:281-300

> Sörensson AA, and others (2010a) Projected precipitation changes in South America: a dynamical downscaling within CLARIS. Meteorol Z 19:347-355

> Sörensson AA, Menéndez CG (2011) Summer soilprecipitation coupling in South America. Tellus Ser A Dyn Meterol Oceanogr 63:56-68

Sörensson AA, Menéndez CG, Samuelsson P, Willén U, Hansson U (2010b) Soil-precipitation feedbacks during the South American Monsoon as simulated by a regional climate model. Clim Change 98:429-447

Stott P, Allen M, Christidis N, Dole RM and others (2013) Attribution of weather and climate-related events. In: Asrar GR, Hurrell JW (eds) Climate science for serving society. Springer Netherlands, Dordrecht, p 307-337

Sugahara S, da Rocha RP, Silveira R (2009) Non-stationary frequency analysis of extreme daily rainfall in Sao Paulo, Brazil. Int J Climatol 29:1339-1349

Taylor KE (2001) Summarizing multiple aspects of model performance in a single diagram. J Geophys Res D 106: 7183-7192

Tedeschi RG, Cavalcanti IFA, Grimm AM (2013) Influences of two types of ENSO on South American precipitation. Int J Climatol 33:1382-1400

Tedeschi RG, Grimm AM, Cavalcanti IFA (2014) Influence of Central and East ENSO on extreme events of precipitation in South America during austral spring and summer. Int J Climatol 35:2045-2064

Tencer B, Rusticucci M (2012) Analysis of interdecadal variability of temperature extreme events in Argentina applying EVT. Atmósfera 25:327-337

- Tencer B, Rusticucci M, Jones P, Lister D (2011) A southeastern South American daily gridded dataset of observed surface minimum and maximum temperature for 19612000. Bull Am Meteorol Soc 92:1339-1346

Uppala SM, KÅllberg PW, Simmons AJ, Andrae U and others (2005) The ERA-40 re-analysis. QJR Meteorol Soc 131:2961-3012

Vargas WM, Naumann G (2008) Impacts of climatic change and low frequency variability in reference series on daily maximum and minimum temperature in southern South America. Reg Environ Change 8:45-57 
Vera CS, Vigliarolo PK (2000) A diagnostic study of coldair outbreaks over South America. Mon Weather Rev 128:3-24

Vera CS, Silvestri G, Barros V, Carril AF (2004) Differences in El Niño response over the Southern Hemisphere. J Clim 17:1741-1753

Vincent LA, Peterson TC, Barros VR, Marino MB and others (2005) Observed trends in indices of daily temperature extremes in South America 1960-2000. J Clim 18: 5011-5023

Yarnal B, Draves JD (1993) A synoptic climatology of stream flow and acidity. Clim Res 2:193-202

Zaninelli P (2015) Climatología numérica del acople suelotemperatura y de períodos secos en Sudamérica: retroacciones, incertidumbre y cambio climático. PhD dissertation, Buenos Aires University

Editorial responsibility: Filippo Giorgi, Trieste, Italy
Zaninelli P, Carril AF, Menéndez CG (2015a) Explorando temperaturas máximas y mínimas en diferentes reanálisis. 1. Campos medios estacionales. Meteorologica 40:43-58

Zaninelli P, Menéndez CG, Carril AF (2015b) Explorando temperaturas máximas y mínimas en diferentes reanálisis. 2. Variabilidad en distintas escalas temporales. Meteorologica 40:59-76

Zhang X and others (2011) Indices for monitoring changes in extremes based on daily temperature and precipitation data. Wiley Interdiscip Rev Clim Chang 2:851-870

Zhou J, Lau KM (1998) Does a monsoon climate exist over South America? J Clim 11:1020-1040

Zhou L, Dickinson RE, Dirmeyer P, Dai A, Min SK (2009) Spatiotemporal patterns of changes in maximum and minimum temperatures in multi-model simulations. Geophys Res Lett 36:2-7

Submitted: June 7, 2015; Accepted: January 8, 2016

Proofs received from author(s): February 11, 2016 